\title{
X11/Mint Genes Control Polarized Localization of Axonal Membrane Proteins in Vivo
}

\author{
Garrett G. Gross, ${ }^{1,3 \star}$ G. Mohiddin Lone, ${ }^{1,3 \star}$ Lok Kwan Leung, ${ }^{1,3}$ Volker Hartenstein, ${ }^{4,5}$ and Ming Guo ${ }^{1,2,3,4}$ \\ ${ }^{1}$ Department of Neurology, University of California, Los Angeles, Los Angeles, California 90095, ${ }^{2}$ Department of Molecular and Medical Pharmacology, \\ University of California, Los Angeles, Los Angeles, California 90095, ${ }^{3}$ Brain Research Institute, The David Geffen School of Medicine, University of \\ California, Los Angeles, Los Angeles, California 90095, ${ }^{4}$ Molecular Biology Institute, University of California, Los Angeles, Los Angeles, California 90095, \\ and ${ }^{5}$ Department of Molecular Cell and Developmental Biology, University of California, Los Angeles, Los Angeles, California 90095
}

Mislocalization of axonal proteins can result in misassembly and/or miswiring of neural circuits, causing disease. To date, only a handful of genes that control polarized localization of axonal membrane proteins have been identified. Here we report that Drosophila X11/Mint proteins are required for targeting several proteins, including human amyloid precursor protein (APP) and Drosophila APP-like protein (APPL), to axonal membranes and for their exclusion from dendrites of the mushroom body in Drosophila, a brain structure involved in learning and memory. Axonal localization of APP is mediated by an endocytic motif, and loss of X11/Mint results in a dramatic increase in cell-surface levels of APPL, especially on dendrites. Mutations in genes required for endocytosis show similar mislocalization of these proteins to dendrites, and strongly enhance defects seen in X11/Mint mutants. These results suggest that X11/Mint-dependent endocytosis in dendrites may serve to promote the axonal localization of membrane proteins. Since X11/Mint binds to APP, and abnormal trafficking of APP contributes to Alzheimer's disease, deregulation of X11/Mint may be important for Alzheimer's disease pathogenesis.

\section{Introduction}

Neurons are highly specialized, polarized cells that contain somatodendritic and axonal compartments, which are morphologically and functionally distinct (Higgins et al., 1997). Membrane and membrane-associated proteins restricted to dendrites or axons are important for diverse functions that include regulation of neurite growth, branching and guidance, and synaptic connectivity (Horton and Ehlers, 2003). Dysfunction and/or mislocalization of membrane proteins can produce misassembly and/or miswiring of neural circuits, causing neuropsychological disorders, such as Alzheimer's disease (AD), schizophrenia, autism, and epilepsy (Aridor and Hannan, 2000, 2002; Sutula, 2004; Stokin et al., 2005; Walsh and Engle, 2010). Accordingly, it is important to identify mechanisms by which membrane proteins are targeted to specific neuronal compartments.

\footnotetext{
Received Dec. 16, 2012; revised March 11, 2013; accepted April 1, 2013.

Author contributions: G.G.G., G.M.L., L.K.L., V.H., and M.G. designed research; G.G.G., G.M.L., and L.K.L. performed research; G.G.G., G.M.L., L.K.L., V.H., and M.G. analyzed data; G.G.G., V.H., and M.G. wrote the paper.

This work was supported by grants and funds from the National Institutes of Health (R01 NS054814 to V.H. and R01 NS48396 to M.G.) and from the Klingenstein Fellowship Awards in the Neurosciences, the Larry P. Hillblom Foundation, the Glenn Family Foundation, and the Alfred P. Sloan Foundation to M.G. We are very grateful to K. White, V. Budnik, L. Luo, Y.N. Jan, K. Matsuno, T. Suzuki, C. Goodman, and D. St. Johnston for fly strains, antibodies, and DNA constructs; to J.H. Wang and H. Huang for experimental assistance; and to A. Sagasti and members of the Hartenstein and Guo laboratories for discussions.

* G.G.G and G.M.L. contributed equally to this work.

Correspondence should be addressed to Ming Guo, MD, PhD, UCLA David Geffen School of Medicine, 695 Charles Young Drive, South, Los Angeles, California 90095-1761. E-mail: mingfly@ucla.edu.

G.G. Gross's present address: Department of Chemistry, University of Southern California, 3710 McClintock Avenue, RTH 522, Los Angeles, California 90089.

DOI:10.1523/JNEUROSCI.5749-12.2013

Copyright $\odot 2013$ the authors $\quad 0270-6474 / 13 / 338575-12 \$ 15.00 / 0$
}

To date, only a handful of genes have been identified as being required for polarized localization of axonal membrane proteins. For example, silencing of NEEP21 (neuron-enriched endosomal protein of $21 \mathrm{kDa}$ ) or EHD1 (Eps15 homology-domain containing protein 1) causes somatodendritic accumulation of the cell adhesion molecule L1/NgCAM in dissociated hippocampal neurons (Yap et al., 2008; 2010; Lasiecka et al., 2010;). Similarly, silencing or expression of a dominant-negative against myosin VI disrupts polarized localization of L1/NgCAM in dissociated cortical neurons (Lewis et al., 2011). Here, we identify X11/Mint as a new regulator of polarized localization of multiple axonal membrane proteins in vivo. Mutations in the amyloid precursor protein (APP) cause familial forms of AD (Tanzi, 2012), the most common neurodegenerative disorder. Sequential cleavage of APP by proteases results in production of cytotoxic $\beta$-amyloid $(\mathrm{A} \beta)$, which leads to synaptic dysfunction and subsequent amyloid plaque formation in AD brains (Tanzi, 2012). X11/ Mint proteins bind to the APP intracellular domain (AICD) (Borg et al., 1996), and are a component of $A \beta$ aggregates (McLoughlin et al., 1999). Overexpression of X11 in APP transgenic mice can ameliorate many $\mathrm{AD}$-like deficits, including $A \beta$ plaque formation, defects in long-term potentiation, and spatial memory impairments (Lee et al., 2003, 2004; Mitchell et al., 2009). In contrast, loss of X11 can enhance $\mathrm{AD}$-like pathology, resulting in increased $\mathrm{A} \beta$ levels and more pronounced electrophysiological deficits (Ho et al., 2006, 2008; Sano et al., 2006; Saito et al., 2008; Saluja et al., 2009; Kondo et al., 2010). How X11/Mint proteins act on APP is poorly understood. Several studies have suggested loss of X11/ Mint affects trafficking and sorting of APP in vitro (Hill et al., 

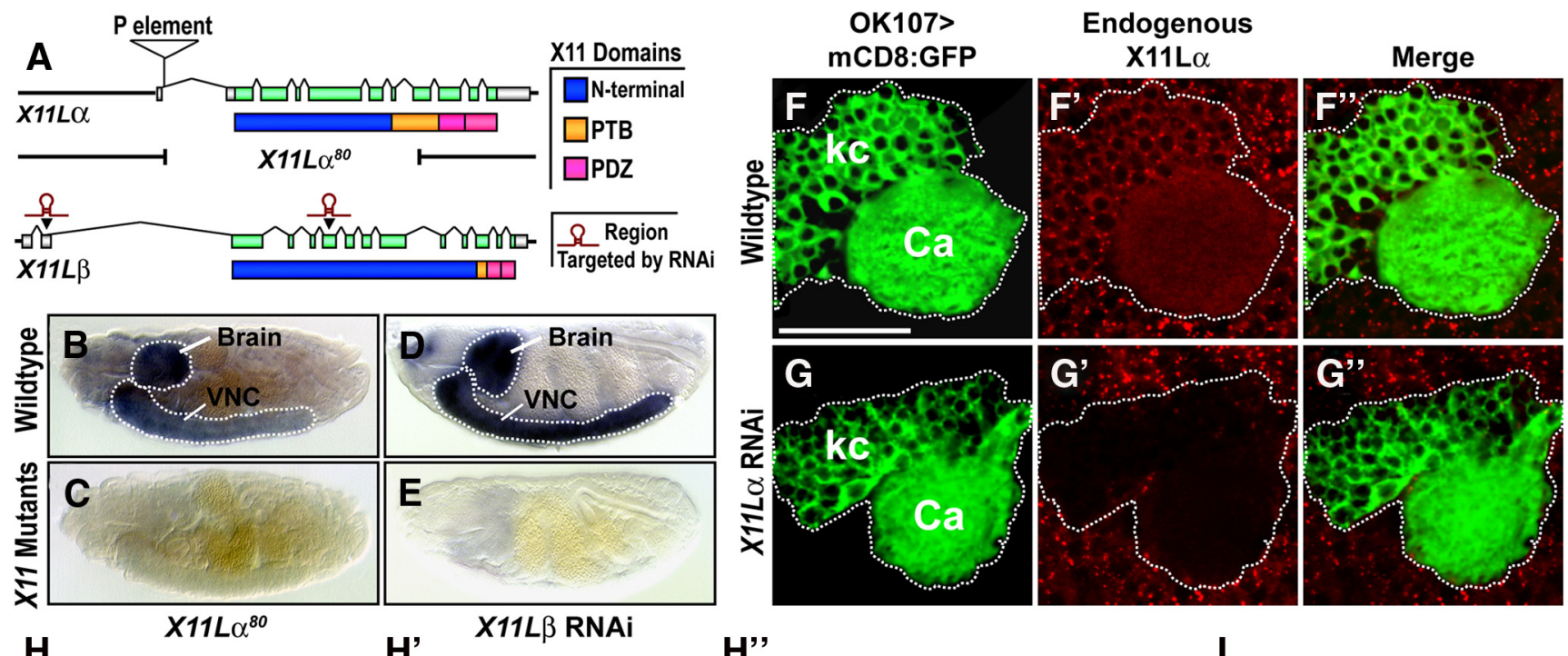

H

Posterior View

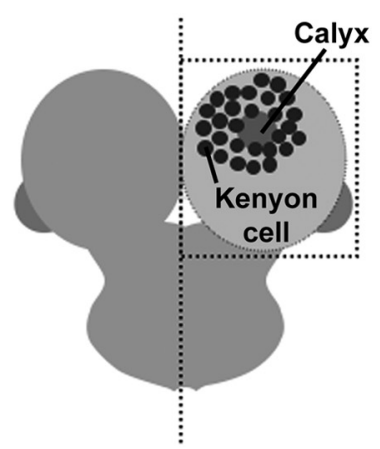

\section{Anterior View}

H"

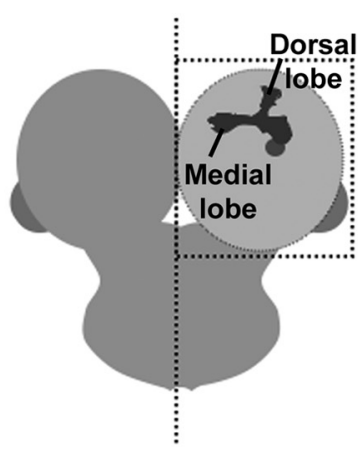

Dorsal View

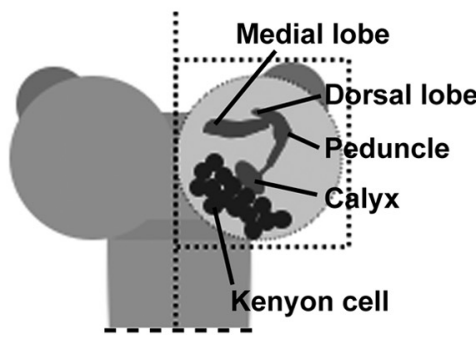

I

$\gamma$ Neuron

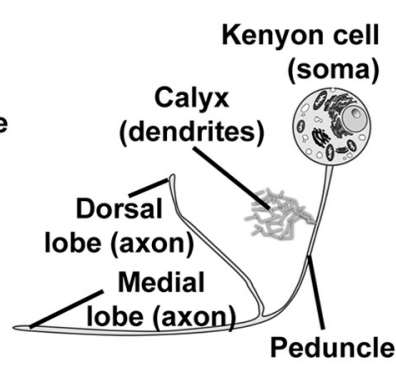

Figure 1. X11 is expressed in the Drosophila CNS. A, Schematic depicting Drosophila X11 paralogs X11L $\alpha$ and X11L $\beta$. X11 proteins consist of a N-terminal domain, PTB domain, and two PDZ domains. Loss-of-function mutant $X 11 L \alpha^{80}$ was generated by imprecise excision of a P element inserted in the $5^{\prime}$ UTR, which also excised a translational start codon, the $N$-terminal domain, and part of the PTB domain. $X 11 L \beta$ was targeted by RNAi technology at two independent regions (black arrows). $\boldsymbol{B}-\boldsymbol{E}$, In situ hybridizations against $X 11 L \alpha(\boldsymbol{B}, \boldsymbol{C})$ or $X 11 L \beta(\boldsymbol{D}, \boldsymbol{E})$ in stage $16 / 17$ embryos indicate $X 11 /$ Mint expression is highest in the CNS, which is outlined by a dotted line. C, Embryos homozygous for $X 11 L \alpha^{80}$ show no detectable $X 11 L \alpha$ transcript in the brain or ventral nerve cord (VNC) of the CNS. $\boldsymbol{E}$, Expression of an RNAi transgene against $X 11 L \beta$ by pan-neuronal driver elav-GAL4 at $29^{\circ} \mathrm{C}$ dramatically reduces $X 11 L \beta$ transcript levels. $\boldsymbol{F}-\boldsymbol{F}^{\prime \prime}$, Larval brains stained with anti-X11L $\alpha$ antibody indicate $X 11 L \alpha($ red) is expressed in the MB, labeled by mCD8-GFP (green) driven by MB-specific driver OK107-GAL4. Kenyon cells (kc) and the calyx (Ca) are visible, which are outlined by a dotted line. The calyx consists of densely packed dendrites, to the extent that cytoplasmic proteins exhibit a diffuse staining pattern when imaged by confocal microscopy. $\mathbf{G}-\mathbf{G}^{\prime \prime}$, An RNAi transgene against X11L $\alpha$ expressed by $0 K 107-G A L 4$ at $29^{\circ} \mathrm{C}$ dramatically reduces X11L $\alpha$ staining in the MB. Scale bar: (in $\left.\boldsymbol{F}\right) \boldsymbol{F}-\mathbf{G}^{\prime \prime}, 50 \mu \mathrm{m} . \boldsymbol{H}-\boldsymbol{H}^{\prime \prime}, \boldsymbol{I}, \boldsymbol{l l l u s t r a t i o n s}$ of the larval MB, which comprises exclusively $\gamma$ neurons $(\boldsymbol{I})$, depict three easy-to-identify neuronal compartments: Kenyon cells (cell bodies), the calyx (dendrites), and lobes (axons). Neurites from Kenyon cells project into the larval brain's posterior neuropile to give rise to dendrites in the calyx $(\boldsymbol{H})$. Axons project further anteriorly as a fasciculated bundle (the peduncle), which eventually bifurcates in the brain's anterior neuropile to give rise to the medial or dorsal lobe, respectively $(\boldsymbol{H})$.

2003; He et al., 2007; Shrivastava-Ranjan et al., 2008; Chaufty et al., 2012). However, how this is accomplished is still unclear.

Previously, we identified Drosophila X11-like $(X 11 L \alpha)$ in an in vivo reporter-based genetic modifier screen as a regulator APP. $X 11 L \alpha$ and human $X 11 \alpha$ function in a conserved manner, independent of APP proteolysis, to modulate activity of the AICD (Gross et al., 2008). X11L $\alpha$ has also been reported to bind the APP ortholog, APP-Like (APPL) (Ashley et al., 2005). Here, we report a new requirement of X11/Mint in excluding APP/APPL and other axonally restricted membrane proteins from dendrites of neurons in the Drosophila mushroom body (MB) (Margulies et al., 2005). Furthermore, we present in vivo evidence that dendritic exclusion of APP/APPL and other axonal membrane proteins is dependent on endocytosis, and that X11/Mint proteins function in endocytosis and/or at Golgi to control polarized localization of axonal membrane proteins.

\section{Materials and Methods}

Molecular biology. A synthetic microRNA technology (miRNA) was used for RNAi silencing (Chen et al., 2007; Deng et al., 2008; Ganguly et al., 2008; Yun et al., 2008). To silence $X 11 L \beta$, the coding region and a 5' UTR were independently targeted. To silence $X 11 L \alpha$, the coding region was targeted. PCR products of these miRNA precursors were cloned into pUASt. To generate UAS-X11L $\alpha$, the $X 11 L \alpha$ cDNA [expression sequence tag (EST) clone from Drosophila Genome Research Center, LD20981], was subcloned into pUASt. All cloned PCR products were confirmed by DNA sequencing. Embryo in situ hybridization of either sex using digoxigenin-labeled probes against X11L $\alpha$ or X11L $\beta$ transcript was performed as described by Hemavathy et al. (1997).

Drosophila genetics and strains. The deletion mutant $X 11 L \alpha^{80}$ was generated by imprecise excision of a previously isolated P element (Gross et al., 2008) in the $5^{\prime}$ UTR of X11L $\alpha$. Breakpoints were mapped by genomic PCR followed by DNA sequencing. UAS- $h X 11 \beta$ was obtained from Kenji Matsuno and Toshiharu Suzuki (Hase et al., 2002); UAS$A P P L$ and UAS-APPL $\Delta c i$ from Kalpana White (Torroja et al., 1999); UAS-Nod-LacZ from Yuh Nung Jan (Clark et al., 1997); UAS-Bazooka- 
A

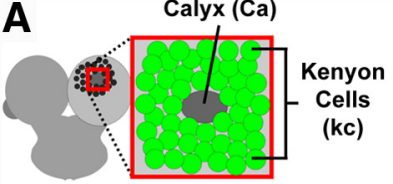

APPL

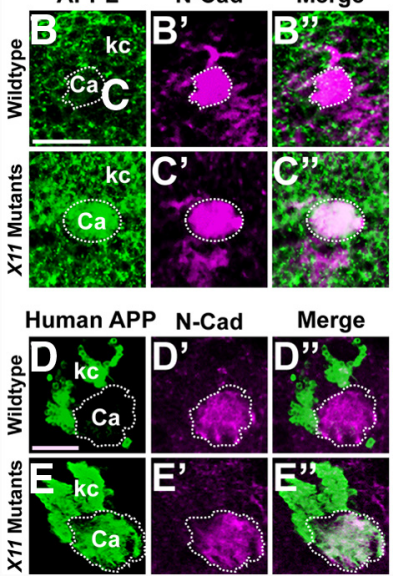

$\mathbf{F}$
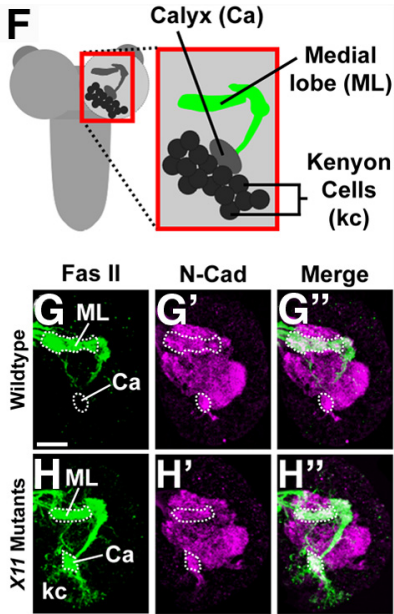

Figure 2. $X 11$ is required in the MB for polarized localization of human APP, APPL, and fasciclin II. $\boldsymbol{B}-\mathbf{E}^{\prime \prime}, \mathbf{G}-\boldsymbol{H}^{\prime \prime}$, Staining of brains against Drosophila N-cadherin (N-Cad, magenta) strongly labels the calyx of the $M B$, which is outlined by a dotted line, allowing for its identification. $\boldsymbol{A}$, An illustration depicts polarized localization of endogenous APPL (green) in Kenyon cells ( $k c$ ) and the calyx ( $(\mathrm{C})$ of a wild-type MB, viewed posteriorly. $\boldsymbol{B}-\boldsymbol{B}^{\prime \prime}$, Wild-type first instar brains stained with anti-APPL antibody indicate APPL (green) is excluded from the MB's calyx. $C-C^{\prime \prime}$, In contrast, brains of $X 11$ mutants stained against APPL show mislocalization of APPL to the calyx and increased levels in Kenyon cells. Scale bar: (in $\boldsymbol{B}) \boldsymbol{B}-\boldsymbol{C}^{\prime \prime}, 10 \mu \mathrm{m}$. D-D", Similarly, third instar brains exogenously expressing myc-tagged human $\mathrm{APP}_{695}$ by MB-specific driver 0K107-GAL4 and stained with anti-Myc antibody indicate ectopic human APP (green) is mostly somatoaxonally localized, with very low levels detectable in the calyx. E-E", However, expression of RNAi transgenes against $X 11$ causes human APP to be dramatically increased in Kenyon cells and the calyx. Scale bar: (in D) $\boldsymbol{D}-\boldsymbol{E}^{\prime \prime}, 50 \mu \mathrm{m}$. B-E", All brains stained against human APP or APPL were imaged from the posterior side. $\boldsymbol{F}$, Illustration depicts polarized localization of endogenous fasciclin II (green) in a wild-type MB, viewed dorsally. G-G", Wild-type first instar brains stained with anti-fasciclin II (Fas II) antibody indicate Fas II (green) is excluded from the calyx and Kenyon cells of the MB. $\boldsymbol{H}-\boldsymbol{H}^{\prime \prime}$, Brains of X11 mutants stained against Fas II show mislocalization of Fas II to the calyx and Kenyon cells, indicating loss of polarized localization. $\mathbf{G}-\boldsymbol{H}^{\prime \prime}$, Brains stained against Fas $\|$ were imaged from the dorsal side. Mislocalization of Fas $\|$ is also visible in brains of $X 11$ mutants imaged from the posterior side. Scale bar, $10 \mu \mathrm{m}$.

GFP from Daniel St. Johnston (Benton and St. Johnston, 2003); UASmCD8-GFP, OK107-GAL4 from Liquin Luo (Lee et al., 1999). Flies carrying elav-GAL4, OK107-GAL4, UAS-APC2-GFP, UAS-shi ${ }^{K 44 A}$, $\alpha$-adaptin ${ }^{06694}\left(A P 2^{06694}\right), U A S-D s c a m . e x o n 17.1-G F P, U A S-G R A S P 65-$ GFP, UAS-KDEL-GFP, UAS-Rab5-GFP, UAS-Rab7-GFP, or FRT19A, tubP-GAL80, hs-FLP were obtained from the Bloomington Drosophila Stock Center. For UAS-X11Lß.RNAi, UAS-X11L $\alpha . R N A i$, and UAS$X 11 L \alpha$ transgenic animals, multiple independent fly lines were generated (Rainbow Transgenic Flies) and tested for each transgene. The recombinant stock FRT19A, X11L $\alpha^{80}$, UAS-X11Lß.RNAi was assembled and confirmed essentially as described by Lee and Luo (1999). The stock FRT19A, tubP-GAL80, hs-FLP; UAS-mCD8-GFP, OK107-GAL4 was constructed using standard genetic techniques. Mitotic clones of $\mathrm{MB}$ neurons homozygous for $X 11 L \alpha^{80}$ and expressing X11Lß.RNAi and $m C D 8$-GFP under OK107-GAL4 were generated as described by Lee et al. for MARCM (mosaic analysis with a repressible cell marker) (Lee et al., 1999).

Immunofluoresence and confocal microscopy. First and/or third instar larval brains of either sex were dissected in $1 \times$ PBS and fixed in $4 \%$ paraformaldehyde for $20 \mathrm{~min}$ at room temperature. Standard staining protocols were used (Ashburner, 1989) for immunocytochemistry. Primary antibodies were used at the following concentrations: rabbit antiAPPL antibody (1:500; Torroja et al., 1996), or rabbit anti-APPL (1:100; D-300, Santa Cruz Biotechnology), mouse anti-fasciclin II (1:10; Gren-
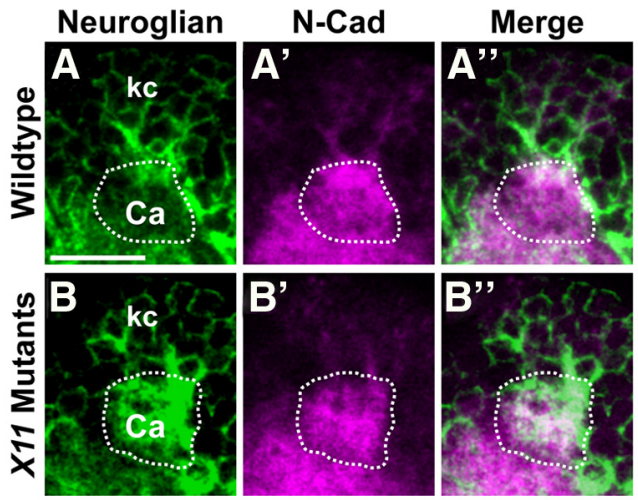

OK107>
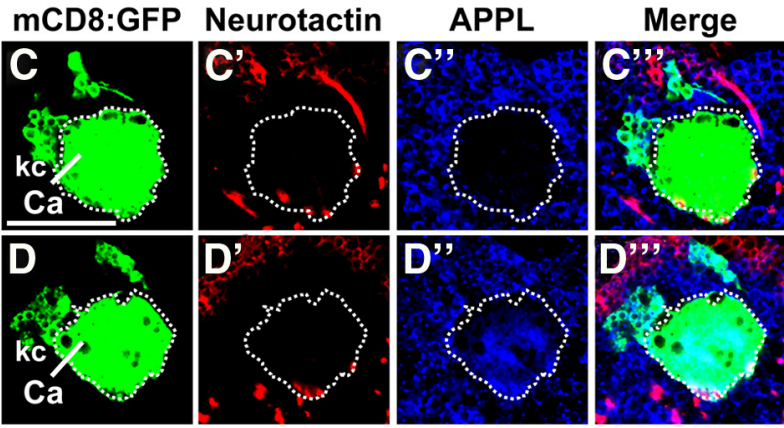

Figure 3. $X 11$ is not required in the MB for polarized localization of all axonal membrane proteins. $\boldsymbol{A}-\boldsymbol{B}^{\prime \prime}$, Staining against Drosophila $\mathrm{N}$-cadherin (N-Cad, magenta) strongly labels the calyx of the MB, which is outlined by a dotted line, allowing for its identification. $\boldsymbol{A}-\boldsymbol{A}^{\prime \prime}$, Wildtype first instar brains stained with anti-neuroglian antibody indicate endogenous neuroglian (green) is mostly somatoaxonally localized in the $M B$, with very low levels detectable in the calyx (Ca). $\boldsymbol{B}-\boldsymbol{B}^{\prime \prime}$, In contrast, brains of X11 mutants stained against neuroglian show mislocalization of neuroglian to the calyx and increased levels in Kenyon cells (kc). Scale bar, $10 \mu \mathrm{m}$. C-D'", mCD8-GFP (green) expressed by MB-specific driver OK107-GAL4 labels Kenyon cells and the calyx, which is outlined by a dotted line, allowing for their identification. C-C'"', Wild-type third instar brains stained with anti-neurotactin antibody indicate endogenous neurotactin (red) is similarly excluded from the MB's calyx. $\mathbf{D}-\mathbf{D}^{\prime \prime \prime}$, However, brains of X11 mutants stained against neurotactin suggest localization of neurotactin, unlike neuroglian or APPL (blue), is not affected by loss of $X 11$ in the MB. Scale bar, $50 \mu \mathrm{m}$. $A-D^{\prime \prime \prime}$, All brains were imaged from the posterior side.

ningloh et al., 1991; 1D4; Hybridoma Bank), mouse anti-Myc (1:100; Millipore), mouse anti-neuroglian (1:10; Hortsch et al., 1990a; BP 104, Hybridoma Bank), rat anti-DN-cadherin (1:20; Iwai et al., 2002; Hybridoma Bank), mouse anti-neurotactin (1:10; Hortsch et al., 1990b; BP 106, Hybridoma Bank), mouse anti- $\beta$-galactosidase (1:50; Sigma-Aldrich), rabbit anti-X11L $\alpha$ (1:25; Gross et al., 2008). Secondary antibodies were purchased from Invitrogen and Jackson Immunoresearch and used at the manufacturer's recommended concentrations. Stained brains were mounted in Vectashield (H-1000, Vector Laboratory).

Confocal images were taken on a Bio-Rad MRC1024ES microscope using LaserSharp version 3.2 software. Complete series of optical sections were taken at 1 or $2 \mu \mathrm{m}$ intervals. Samples from each experiment were imaged at equal intensity and magnification settings for comparison. Images were analyzed and assembled using ImageJ (United States National Institutes of Health).

APPL cell-surface labeling experiments. For analysis of cell-surface APPL in larval brains, dissected, live brains of either sex were incubated in Schneider's Drosophila Media (Invitrogen) supplemented with $10 \%$ fetal bovine serum (Invitrogen) and a rabbit polyclonal anti-APPL antibody against the extracellular domain of APPL (1:10; Torroja et al., 1996) for $4 \mathrm{~h}$ at $4^{\circ} \mathrm{C}$. At which time, brains were moved to $30^{\circ} \mathrm{C}$ for $6 \mathrm{~h}$ to overnight. This chase step was necessary to allow efficient penetration of the APPL antibody through glia that ensheath the brains. During incubation of brains with APPL antibody, some APPL bound by antibody was internalized into neurons. Live brains were subsequently washed several 

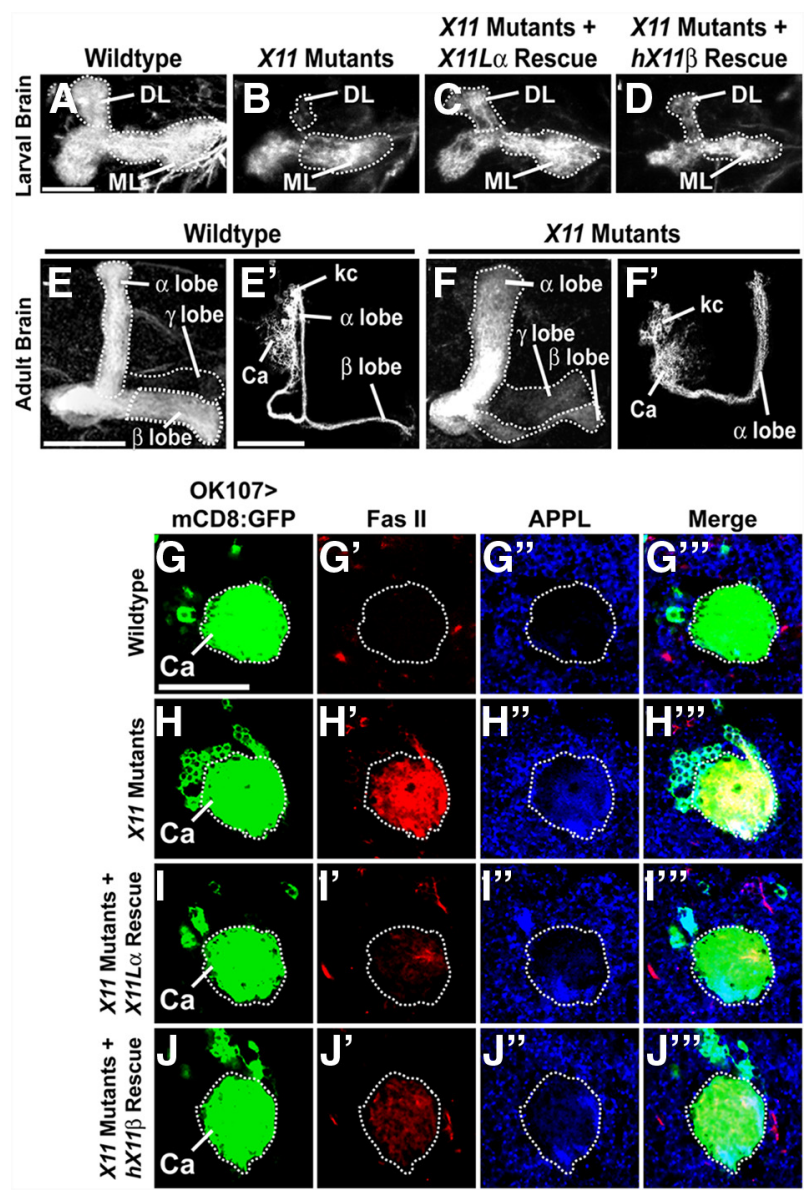

Figure 4. Ectopic expression of $X 11 L \alpha$ or human $X 11 \beta$ partially rescues defects in the MB of X11 mutants. $A-D$, First instar brains stained with anti-fasciclin II (Fas II) antibody. Scale bar, 10 $\mu \mathrm{m} . A$, In wild-type brains, Fas II staining labels the MB's dorsal lobe (DL) and medial lobe (ML), which are outlined by dotted lines. $\boldsymbol{B}, \ln X 11$ mutants the DL is drastically reduced and the ML misshapen, indicating aberrant axon development in $\gamma$ neurons. These structural defects are partially rescuable by expression of $X 11 L \alpha(C)$ or, to a lesser extent, human $X 11 \beta(D)$ by panneuronal driver elav-GAL4. Expression of RNAi transgenes against $X 11$ by MB-specific driver OK107-Gal4 does not cause structural phenotypes in the larval MB, suggesting larval lobe defects in X11 mutants may arise nonautonomously. $\boldsymbol{E}-\boldsymbol{F}^{\prime}$, However, MB-specific silencing of X11 by RNAi does cause lobe defects in the adult brain. Adult brains stained against Fas II with MB-specific silencing of X11 by RNAi show dramatic widening of the $\alpha$ lobe, shrinkage of the $\gamma$ lobe, and severe thinning of the $\beta$ lobe compared with wild type $(\boldsymbol{E}$ vs $\boldsymbol{F})$. Mitotic clones from an MB neuroblast homozygous for $X 11 L \alpha^{80}$ and expressing RNAi $X 11 L \beta$ and mCD8-GFP suggest that axonal tracts of $\alpha / \beta$ neurons project aberrantly to the $\alpha$ lobe ( $\boldsymbol{E}^{\prime}$ vs $\left.\boldsymbol{F}^{\prime}\right)$. Scale bar, $50 \mu \mathrm{m}$. $A-F^{\prime}$, Brains showing lobes of the MB were imaged from the anterior side. G-J'", mCD8-GFP (green) driven by 0K107-GAL4 labels Kenyon cells ( $k c$ ) and the calyx (Ca), which are outlined by dotted lines, allowing for their identification. In the third instar MB of $X 11$ mutants dendritically mislocalized APPL (blue) $\left(\boldsymbol{H}^{\prime \prime}\right)$ and fasciclin II (red) $\left(\boldsymbol{H}^{\prime}\right)$ can be partially rescued to wild type $\left(\mathbf{G}-\mathbf{G}^{\prime \prime \prime}\right)$ by expression of X11L $\alpha\left(\boldsymbol{I}-\boldsymbol{I}^{\prime \prime \prime}\right)$ or, to a lesser extent, human X11 $\beta\left(J-J^{\prime \prime \prime}\right) . \mathbf{G}-J^{\prime \prime \prime}$, Brains showing the calyx were imaged from the posterior side. Scale bar, $50 \mu \mathrm{m}$.

times in ice-cold $1 \times$ PBS and fixed in 4\% paraformaldehyde for 20 min at room temperature. Fixed brains were then blocked for $1 \mathrm{~h}$ with $10 \%$ normal goat serum in $1 \times$ PBS at room temperature. Afterward, brains were incubated in secondary antibody in $1 \times \mathrm{PBS}$ overnight at $4^{\circ} \mathrm{C}$. The next day, brains were washed briefly in $1 \times$ PBS and fixed again for $5 \mathrm{~min}$ in $4 \%$ paraformaldehyde at room temperature to prevent loss of secondary antibody during later washes. Up until this point, brains were never exposed to permeabilizing conditions (i.e., detergent). Only after surface labeling of APPL was complete were standard staining protocols used (Ashburner, 1989). As a final step, brains were immunostained against $\mathrm{DN}$-cadherin to label the neuropile, as described in the immunofluoresence and confocal microscopy section.
Monoclonal antibodies against neuroglian (BP 104), 1:5, or fasciclin II (1D4), 1:5, were used as negative staining controls for these experiments, to determine whether cell-surface labeling of APPL worked. The epitopes for these antibodies are reported to be strictly cytoplasmic (Hortsch et al., 1990a; Grenningloh et al., 1991). No immunostaining above background was ever observed in larval brains when using the described protein cell-surface labeling protocol with control antibodies. However, strong staining was observed when cell membranes were permeabilized using $0.1 \%$ Triton $\mathrm{X}-100$.

\section{Results}

$X 11$ is required for polarized localization of APP/APPL and multiple other axonal membrane proteins

Human and mammalian genomes contain three X11/Mint para-

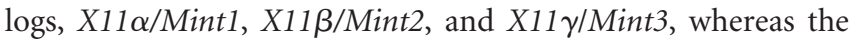
Drosophila melanogaster genome contains only two, X11L $\alpha$ (CG5675) and X11L $\beta$ (CG32677). All of these proteins contain a single phosphotyrosine binding (PTB) and two postsynaptic density protein, Drosophila disc large tumor suppressor, zonula occludens-1 protein (PDZ) domains (Rogelj et al., 2006; Vishnu et al., 2006). The two Drosophila X11L proteins share $85 \%$ amino acid identity in their PTB and PDZ domains, and the expression of both is restricted to differentiated neurons in the CNS (Hase et al., 2002; Vishnu et al., 2006). These findings raise the possibility that $\mathrm{X} 11 \mathrm{~L} \alpha$ and $\mathrm{X} 11 \mathrm{~L} \beta$ proteins are functionally redundant. While flies with partial loss of function of X11L $\alpha$ are viable, and have only mild neuromuscular junction phenotypes (Ashley et al., 2005; Vishnu et al., 2006), phenotypes of flies lacking $X 11 L \beta$ have not been reported. Utilizing a $\mathrm{P}$ element inserted in the $5^{\prime}$ UTR of $X 11 L \alpha$, we generated a large deletion, $X 11 L \alpha^{80}$ (Fig. $1 A$ ). $X 11 L \alpha^{80}$-mutant embryos contain no detectable $X 11 L \alpha$ transcript (Fig. $1 B, C$ ), suggesting $X 11 L \alpha^{80}$ is a null allele. Since no loss-of-function mutants of $X 11 L \beta$ are available, we generated two synthetic miRNA-expressing transgenic fly lines targeting two distinct regions of $X 11 L \beta$ (Fig. $1 A$ ). Embryos from flies expressing either construct using the UAS-GAL4 system (Brand and Perrimon, 1993) show robust silencing of the X11L $\beta$ transcript (Fig. 1D,E), and they produced highly similar if not identical phenotypes when coupled with $X 11 L \alpha^{80}$ or miRNAs targeting $X 11 L \alpha$ we generated (Fig. $1 F-G$ '). Flies lacking $X 11 L \alpha$ $\left(X 11 L \alpha^{80}\right)$, or flies with pan-neuronal silencing of $X 11 L \beta$ alone, are viable and adults are wild type in appearance. In contrast, by pan-neuronal silencing of both $X 11 L$ genes, or by combining the $X 11 L \alpha^{80}$-null allele with pan-neuronal expression of miRNAs targeted against $X 11 L \beta$ (hereafter referred to as X11 mutants in either case), we obtained early to mid-third instar larval lethality, suggesting that these two $X 11 \mathrm{~L}$ genes carry out redundant functions in neurons.

We focused our studies on the Drosophila MB, a brain structure that shares functional similarities with the mammalian hippocampus in mediating learning and memory. AD patients show pronounced neuronal dysfunction in the hippocampus (Blennow, 2006). Immunostaining of wild-type larval brains shows that X11/Mint protein is present in the MB (Fig. 1F-F"'; compare with Fig. $1 G-G$ ", in which $X 11$ has been silenced) (Margulies et al., 2005). The MB of the early larval brain comprises exclusively a single class of neuron, the $\gamma$ neuron. At later stages of the Drosophila lifecycle, the composition and circuitry of the MB becomes considerably more complex as additional classes of neurons $\left(\alpha, \beta, \alpha^{\prime}\right.$, and $\left.\beta^{\prime}\right)$ are born and incorporated during extensive developmental remodeling (Lee et al., 1999). Accordingly, we limited our investigation mainly to early larval brains. Briefly, all $\gamma$ neuron cell bodies (Kenyon cells) project their dendrites into the larval brain's posterior neuropile, 

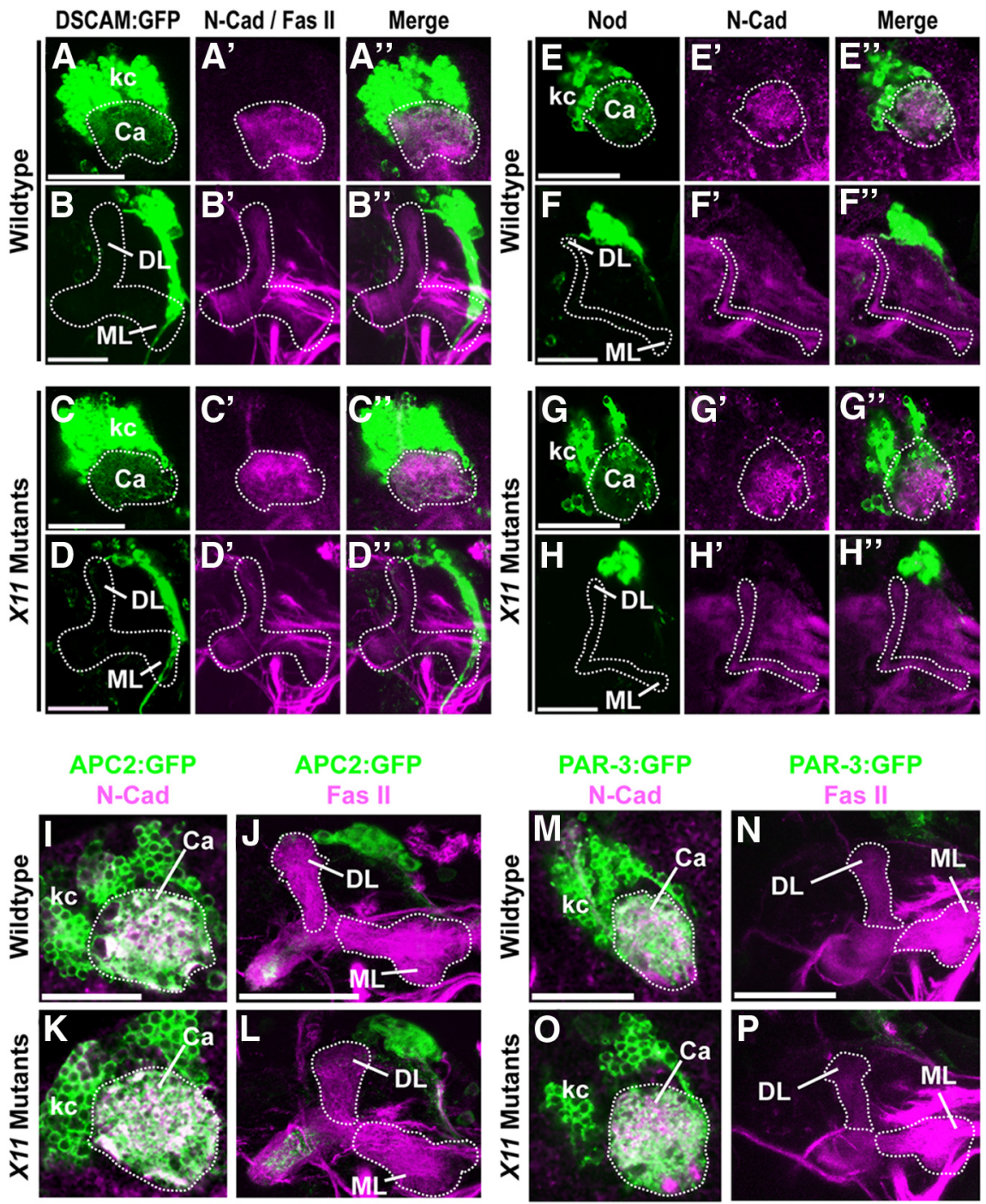

Figure 5. Neuronal polarity is unaffected in $M B$ neurons of $X 11$ mutants. $\boldsymbol{A}-\boldsymbol{P}$, Third instar brains expressing tagged dendritic proteins in the MB. Scale bar, $50 \mu \mathrm{m}$. Staining of brains against $\mathrm{N}$-cadherin ( $\mathrm{N}$-Cad; magenta) identifies the calyx of the MB, while staining against either $\mathrm{N}$-Cad (magenta) or Fas II (magenta) is used to identify the lobes. These structures are outlined by dotted lines. $\boldsymbol{A}-\boldsymbol{B}^{\prime \prime}$, Wild-type brains expressing a dendritically restricted splice form of DSCAM-GFP (green), containing exon 17.1, driven by OK107-GAL4, show DSCAM[exon 17.1] is somatodendritically restricted. DSCAM[exon 17.1] is detectable in Kenyon cells (kc) and the calyx, but not in the medial lobe (ML) or dorsal lobe (DL) of the MB. $C-D^{\prime \prime}$, Brains of X11 mutants with MB-specific expression of DSCAM-GFP indicate DSCAM[exon 17.1] localization is not affected by loss of X11.E-F", Wild-type brains expressing Nod-LacZ (green) by OK107-GAL4, stained with anti- $\beta$-gal antibody, show Nod is also somatodendritically restricted. $\mathbf{G}-\boldsymbol{H}^{\prime \prime}$, MB-specific expression of Nod-LacZ in brains of X11 mutants, stained against $\beta$-gal, suggests that loss of X11/Mint does not change compartmental localization of Nod. I-P, Similarly, MB-specific expression of APC2-GFP (green) or PAR-3/Bazooka-GFP (green) in wild-type brains $(\boldsymbol{I}, J, M, N)$ versus in $X 11$ mutants $(\boldsymbol{K}, \boldsymbol{L}, \mathbf{O}, \boldsymbol{P})$ indicates somatodendritic localization of APC2 and PAR-3/Bazooka is not affected by loss of $X 11$.

which comprises the calyx (Fig. $1 H$ ). Axons of $\gamma$ neurons in the larval MB fasciculate in the peduncle, which extends anteriorly, until each axon bifurcates to project one branch toward the brain's midline and another branch dorsally (Lee et al., 1999; Heisenberg, 2003). The fasciculated axons of these branches form the MB's medial lobe and dorsal lobe, respectively (Fig. $1 H^{\prime}$ ). In summary, the structure of the larval MB is subdivided into three distinct, easily identifiable compartments that contain the cell bodies (Kenyon cells), axons (lobes), or dendrites (calyx) of $\gamma$ neurons (Fig. $1 H^{\prime \prime}, I$ ).

APPL protein is also strongly expressed in the MB (Torroja et al., 1996; Li et al., 2004). We note that in wild-type $\gamma$ neurons, APPL is exclusively somatoaxonally localized, being excluded
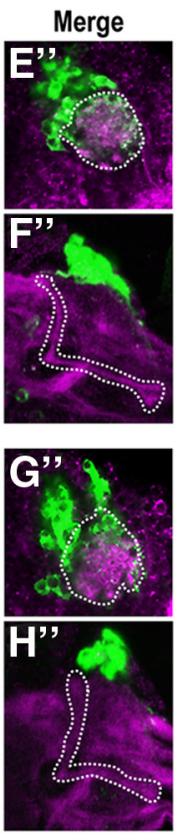

from dendrites (Fig. 2A-B"). In contrast, polarized localization of APPL is severely disrupted in X11 mutants. Instead of APPL being restricted to the Kenyon cells and lobes of the MB, in X11 mutants APPL mislocalizes to the calyx (Fig. $2 C-$ $\left.C^{\prime \prime}\right)$. Because of this finding, we also investigated localization of human APP ectopically expressed in X11 mutants. Like endogenous APPL, ectopic human APP is mostly somatoaxonally restricted in wild-type MB neurons (Fig. 2D-D"), while in X11 mutants, human APP is found in the calyx as well (Fig. 2E-E'). These results suggest that human APP contains a signal sufficient to specify its compartmental localization in $\gamma$ neurons and that X11/Mint may use a conserved mechanism to exclude APP and APPL from dendrites of $\mathrm{MB}$ neurons.

Since APPL has previously been reported to form a tripartite complex with $\mathrm{X} 11 \mathrm{~L} \alpha$ and fasciclin II (Fas II) (Ashley et al., 2005), the Drosophila ortholog of neural cell adhesion molecule (NCAM), we also examined Fas II localization in the MBs of X11 mutants. As with APP/APPL, Fas II is axonally restricted in wild-type $\gamma$ neurons (Fig. $2 F-G$ "). However, in X11 mutants, we found that Fas II is similarly mislocalized to the calyx (Fig. $2 H-H^{\prime \prime}$ ). This mislocalization of Fas II is visible in brains imaged from their dorsal or posterior sides. To determine whether disruption of polarized localization in X11 mutants is limited to APP/APPL and Fas II, or is more extensive, we examined larval MBs using antibodies against neuroglian $(\mathrm{Nrg})$, an ortholog of L1/NgCAM, or the cell adhesion molecule neurotactin (Nrt). Neither Nrg nor Nrt share sequence homology with APPL or Fas II, or are known to bind X11/Mint. Nevertheless, like APPL and Fas II, both Nrg and Nrt are axonally restricted in wild-type $\gamma$ neurons of the MB (Fig. $3 A-A$ "). Interestingly, although we observed dendritic mislocalization of Nrg to the MB's calyx in X11 mutants (Fig. 3B-B"), we did not detect similar mislocalization of $\mathrm{Nrt}$ (Fig. 3C-D"'). Together, these findings indicate that X11/ Mint proteins regulate the polarized localization of a subset of axonal membrane proteins, including APP/APPL, Fas II, and Nrg, but not Nrt.

Along with mislocalization of multiple axonal membrane proteins, we observed structural defects in the MB lobes of X11 mutants. Formation of the dorsal lobe during MB development is aberrant in most X11 mutants, causing it to be severely truncated (Fig. $4 A, B$ ). In addition, the medial lobe appears frayed and misshapen, indicating abnormal axon development. When we specifically silence X11/Mint expression in $\mathrm{MB}$, which is a structure dispensable for viability (Margulies et al., 2005), flies survived to adulthood, with gross structural 


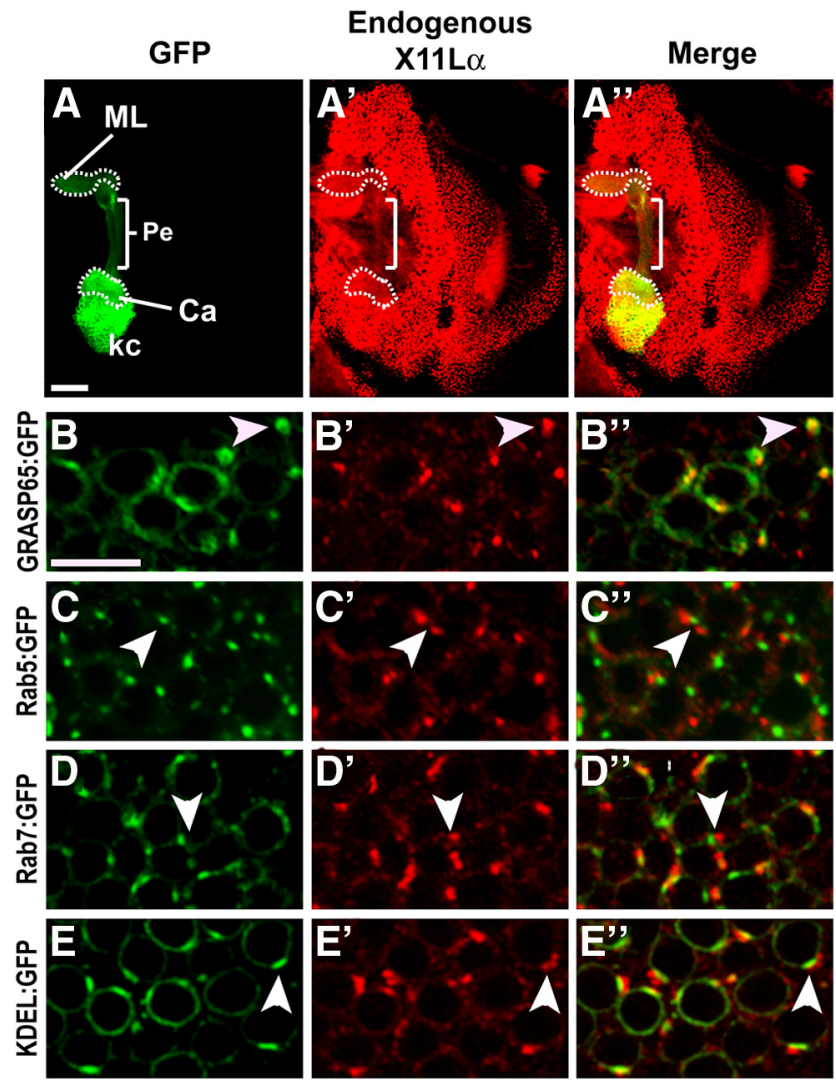

Figure 6. $\mathrm{X} 11 \mathrm{~L} \alpha$ is present at Golgi, dendrites, and axons in MB neurons. $\boldsymbol{A}-\boldsymbol{A}^{\prime \prime}$, Third instar wild-type brains stained against $\mathrm{X} 11 \mathrm{~L} \alpha$ indicate moderate levels of $\mathrm{X} 11 \mathrm{~L} \alpha$ are present in the peduncle $(\mathrm{Pe})$, calyx $(\mathrm{Ca})$, medial lobe $(\mathrm{ML})$, and dorsal lobe of the $\mathrm{MB}$, which are labeled by mCD8-GFP (green) expressed by 0K107-GAL4. Scale bar, $50 \mu \mathrm{m}$. $\boldsymbol{B}-\boldsymbol{E}^{\prime \prime}$, Third instar brains stained against $\mathrm{X} 11 \mathrm{~L} \alpha$ expressing various GFP-tagged subcellular markers by MB-specific driver 0K107-GAL4. Scale bar, $10 \mu \mathrm{m}$. $\boldsymbol{B}-\boldsymbol{B}^{\prime \prime}$, Larval brains stained with anti-X11L $\alpha$ antibody show strong X11L $\alpha$ (red) colocalization with the Golgi marker GRASP65-GFP (green) in Kenyon cells (kc). C C ', In contrast, X11L $\alpha$ staining poorly colocalizes with the early endosome marker Rab5-GFP (green) and only mildly colocalizes with the late endosome marker (D-D') Rab7-GFP (green) or the endoplasmic reticulum marker $\left(\boldsymbol{E}-\boldsymbol{E}^{\prime \prime}\right)$ KDEL-GFP (green).

defects in the lobes (Fig. $4 E-F^{\prime}$ ). Importantly, we were able to partially rescue axonal membrane protein mislocalization and structural defects in the MB of X11 mutants by ectopically expressing $X 11 L \alpha$ or human $X 11 \beta$ (Fig. $4 C, D, G-J$ '”). These results indicate that functions of X11/Mint are partially conserved between flies and humans.

Neuronal polarity is unaffected in X11 mutants

Mislocalization of axonal proteins in X11 mutants could be due to loss of dendritic compartment identity. To investigate this possibility, we compared the localization of several putative dendritic markers in the MB of X11 mutants versus wild-type animals. A dendritically restricted splice form of the Drosophila membrane protein DSCAM (Down syndrome cell adhesion molecule), which contains exon 17.1 (Wang et al., 2004), is expressed exclusively in membrane of the somatodendritic compartment in wild-type MB neurons (Fig. 5A-B'). Importantly, in X11 mutants, this localization was unchanged (Fig. $5 C-D$ "). Nod, APC2, and PAR-3/Bazooka, well characterized cytoskeleton regulators, also exhibited restricted somatodendritic localization in the $\mathrm{MB}$ of wild-type animals (Rolls et al., 2007) and X11 mutants (Fig. $5 E-P$ ). In summary, neither DSCAM[exon 17.1], Nod, APC2, nor PAR-3/Bazooka mislocalizes to axons of $\gamma$ neurons lacking
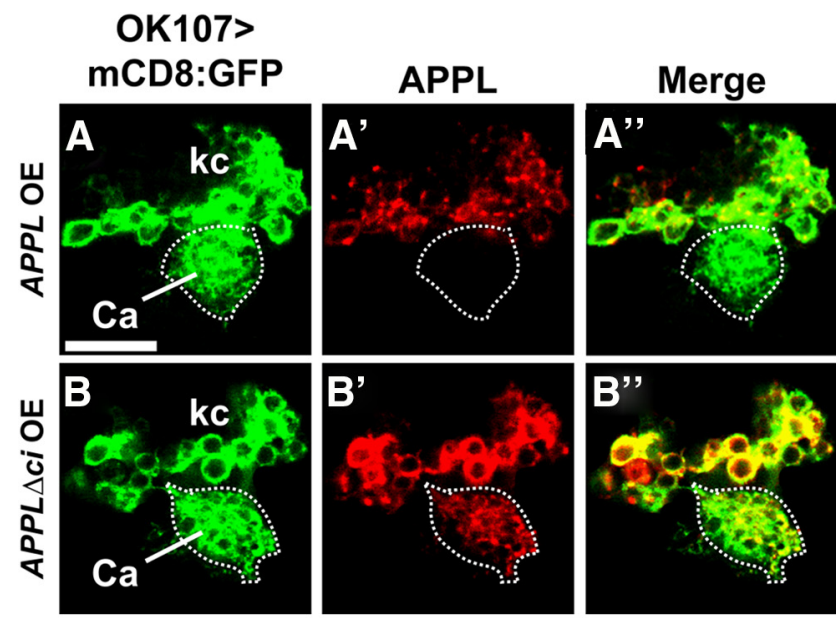

APPL Surface

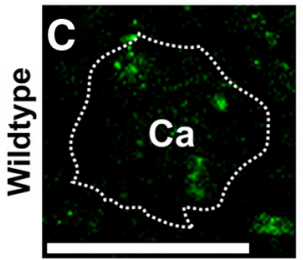

N-Cad

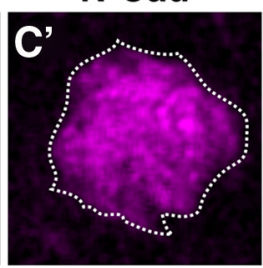

Merge
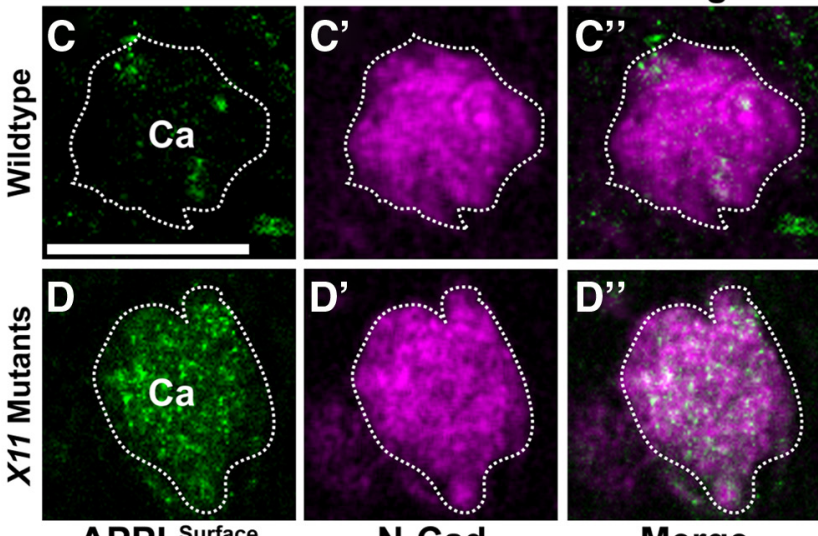

APPL Surface
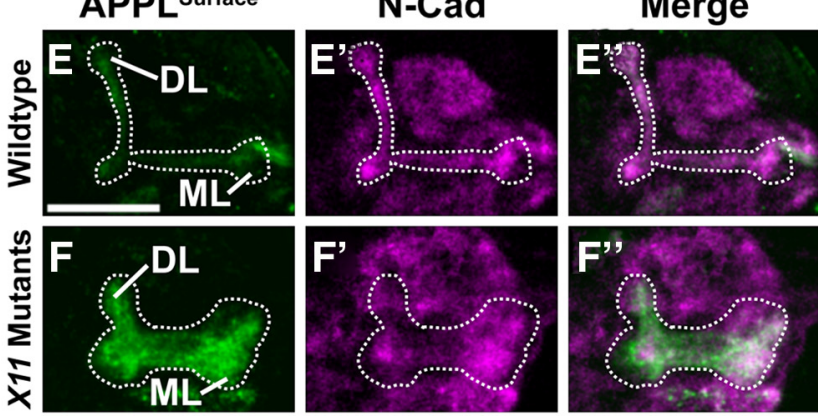

Figure 7. APPL requires an endocytic motif for dendritic exclusion, and is increased on the dendritic surface of MB neurons in X11 mutants. $\boldsymbol{A}-\boldsymbol{B}^{\prime \prime}, \mathrm{mCD} 8$-GFP (green) expressed in larval brains by MB-specific driver OK107-GAL4 labels Kenyon cells ( $k c$ ) and the calyx (Ca; dotted line). Scale bar, $10 \mu \mathrm{m}$. $A-A^{\prime \prime}$, First instar brains homozygous for appl $P^{2}$, a null allele, overexpressing wild-type APPL by OK107-GAL4, and stained with anti-APPL antibody indicate ectopic APPL (red) is excluded from the calyx. $\boldsymbol{B}-\boldsymbol{B}^{\prime \prime}$, In contrast, similar MB-specific expression of $A P P L \Delta c i$, which removes the highly conserved motif GYENPTY, shows APPL staining mislocalized to the calyx. C-F", Since the GYENPTY motif is involved in endocytosis of APPL, live third instar brains of X11 mutants were labeled with an anti-APPL antibody against APPL's extracellular domain to detect cell-surface levels of APPL. Staining of brains against Drosophila N-cadherin (N-Cad, magenta) labels the calyx and lobes of the $M B$, which are outlined by dotted lines, allowing for their identification. Brains of $X 11$ mutants show abnormal levels of APPL (green) on the surface of the calyx ( $\left.\boldsymbol{D}-\boldsymbol{D}^{\prime \prime}\right)$ versus wild type $\left(\boldsymbol{C}-\boldsymbol{C}^{\prime \prime}\right)$. Scale bar, $50 \mu \mathrm{m}$. In addition, levels of APPL appear increased on the surface of the $M B^{\prime}$ s lobes in $X 11$ mutants $\left(\boldsymbol{F}-\boldsymbol{F}^{\prime \prime}\right)$ versus wild type $\left(\boldsymbol{E}-\boldsymbol{E}^{\prime \prime}\right)$. These results indicate APPL's endocytosis at the plasma membrane in dendrites and axons in MB neurons may be impaired.

X11/Mint. These findings, together with our previous observation that axonally restricted neurotactin (Nrt) does not mislocalize to dendrites in $X 11$ mutants, indicate that neuronal polarity is unaffected in MB neurons lacking X11/Mint. Thus, a disruption 
of polarized localization of axonal proteins in X11 mutants must have a different cause.

X11/Mint is localized to Golgi, dendrites, and the axon of the MB neurons

To gain insight into how X11/Mint controls polarized localization of membrane proteins at the cellular level, we examined the expression pattern of X11L $\alpha$ using an anti-X11L $\alpha$ antibody (Gross et al., 2008). In the brain, X11L $\alpha$ is expressed in most, if not all, neurons (Fig. 4A-A"). In $\gamma$ neurons of the MB, X11L $\alpha$ exhibits a diffuse, but still highly specific, staining pattern in the lobes and calyx of the MB. The subcellular localization of Drosophila X11 proteins has not been reported. To explore this question, we double-labeled MB neurons using various markers for subcellular compartments. X11L $\alpha$ has a punctate cytoplasmic pattern that strongly colocalizes with the Golgi marker GRASP65-GFP (Barr et al., 1997) in the soma of $\gamma$ neurons (Fig. $6 B-B$ "). X11L $\alpha$ was also localized adjacent to structure labeled with an early endosomal marker Rab5-GFP (Fig. $6 C-C^{\prime \prime}$ ), a late endosomal marker, Rab7-GFP (Fig. 6D-D"), and an endoplasmic reticulum (ER) marker, KDEL-GFP (lysine-aspartic acidglutamic acid-leucine-GFP) (Fig. $6 E-E$ "). However, as the MB neurons are quite small, due to limitations on the resolution of images obtained by confocal microscopy, we cannot exclude the possibility that $\mathrm{X} 11 \mathrm{~L} \alpha$ may also partially colocalize with these compartments.

An endocytic motif (GYENPTY) in APP/APPL is required for its dendritic exclusion in $\mathrm{MB}$ neurons

Previously we reported that X11L $\alpha$ regulates APP through its intracellular domain (AICD) (Gross et al., 2008), which contains a putative GYENPTY motif. This highly conserved motif is necessary for X11/Mint to directly bind to APP and APPL (Borg et al., 1996; Ashley et al., 2005). The GYENPTY motif has also been suggested to be important for recruitment of many membrane proteins, including APP, to clathrin-coated pits at the plasma membrane via binding to clathrin adaptor proteins to facilitate their rapid endocytosis (for review, see Bonifacino and Traub, 2003). To determine whether this motif might be important for dendritic exclusion of APP/APPL in neurons, we ectopically expressed a mutant form of APPL with the GYENPTY motif removed (APPL $\Delta$ ci) (Torroja et al., 1999; Ashley et al., 2005) in larval MB neurons null for endogenous appl. Interestingly, MBspecific expression of $a p p l \Delta c i$, but not wild-type appl, led to mislocalization of APPL to the calyx (Fig. 7A-B'). This suggests that the GYENPTY motif in APP/APPL's cytoplasmic domain is required for APPL's dendritic exclusion in MB neurons, and that endocytosis of APPL from dendrites may contribute to its polarized localization.

\section{APPL accumulates on the surface of MB neurons in \\ X11 mutants}

To explore the possibility that lack of X11/Mint leads to an endocytosis defect, we asked whether APPL in the X11-mutant brain accumulates on the surface of MB neurons. Live, larval brains were labeled with a polyclonal antibody against the extracellular domain of APPL (Torroja et al., 1996). Binding of anti-APPL antibody was done in the absence of membrane-permeabilizing detergent, so as to label only cell-surface APPL. Mislocalized APPL was observed on the dendritic membrane of the MB's calyx in X11 mutants (Fig. 7E-E"), whereas little or no APPL was detectable on the dendritic membrane in the calyx of wild-type brains (Fig. $7 D-D$ "). In addition, we observed increased levels of

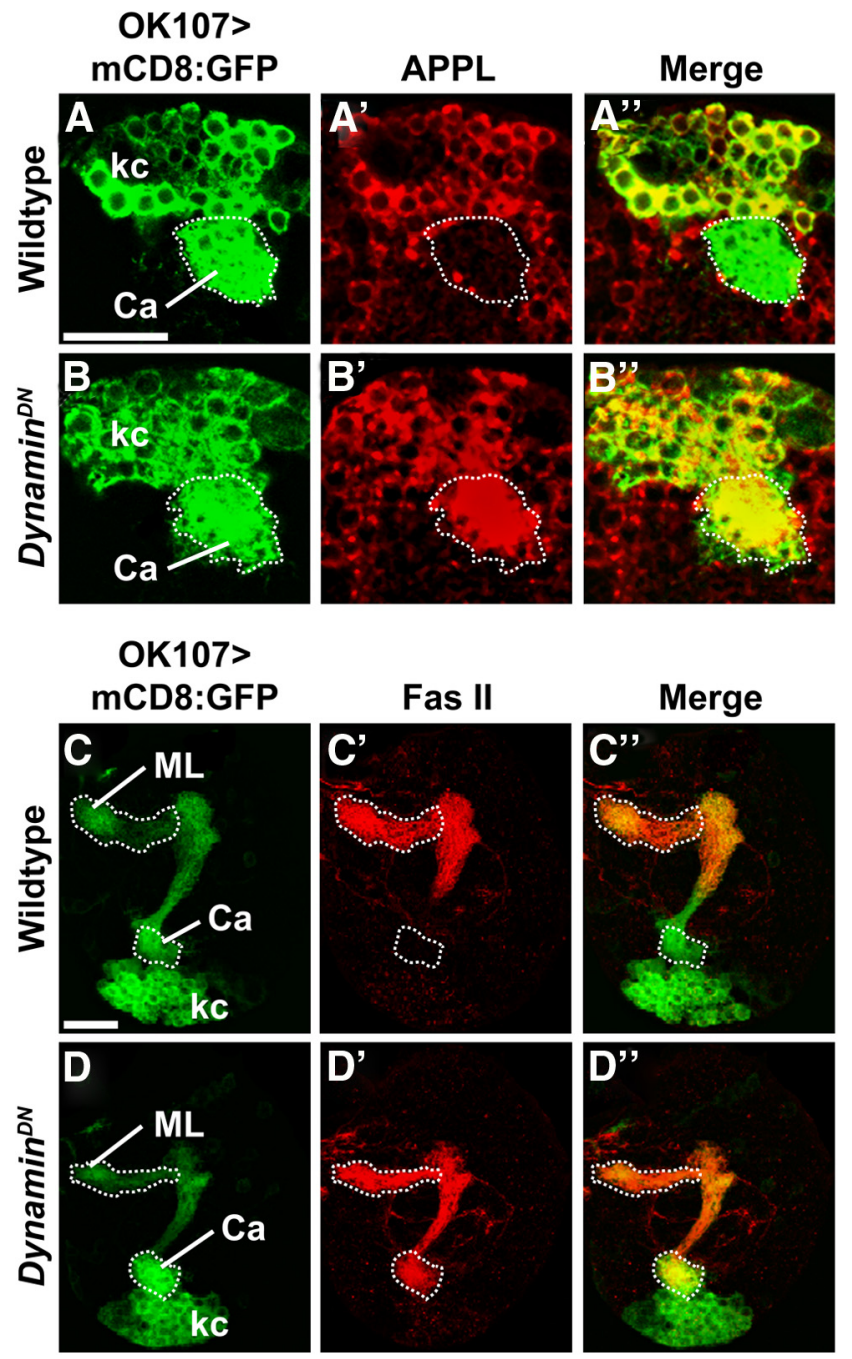

Figure 8. Dynamin-dependent endocytosis is required for dendritic exclusion of APPL and other axonal membrane proteins in MB neurons. $A-D^{\prime \prime}$, mCD8-GFP (green) expressed in first instar brains by MB-specific driver 0K107-GAL4 labels Kenyon cells ( $\mathrm{kc})$, the medial lobe (ML), and the calyx (Ca), which are outlined by dotted lines. Scale bar, $10 \mu \mathrm{m}$. Brains stained with anti-APPL antibody strongly overexpressing dominant-negative dynamin/shibire (Dynamin ${ }^{\mathrm{DN}}$ ) by 0K107-GAL4 at $29^{\circ} \mathrm{C}$ show mislocalization of endogenous APPL (red) to the calyx of the MB $\left(\boldsymbol{A}-\boldsymbol{A}^{\prime \prime}\right.$ vs $\left.\boldsymbol{B}-\boldsymbol{B}^{\prime \prime}\right)$. Similarly, brains stained with anti-fasciclin II (Fas II) antibody strongly overexpressing dynamin ${ }^{D N}$ in the MB show mislocalization of endogenous Fas II (red) (C-C" vs $\left.D-D^{\prime \prime}\right)$ to the calyx. Brains stained against APPL were imaged from the posterior side; brains stained against Fas II were imaged from the dorsal side.

cell-surface APPL on the MB's lobes in X11/Mint mutants versus wild-type animals (Fig. $\left.7 E-F^{\prime \prime}\right)$. The accumulation of APPL on the surface of the MB's calyx and lobes in X11 mutants is consistent with the idea that X11/Mint regulates the trafficking and/or endocytosis of APPL at the surface of neuronal compartments in $\gamma$ neurons.

Inhibition of dynamin/shibire causes APPL and other axonal membrane proteins to mislocalize to dendrites in $\mathrm{MB}$ neurons

An accumulating body of evidence suggests that in mammalian neurons several axonal membrane proteins, including the cell adhesion molecule L1/NgCAM, are trafficked from the transGolgi network (TGN) to the somatodendritic surface, where they are rapidly removed by endocytosis for sorting into carrier vesicles targeted to the axon (Sampo et al., 2003; Bel et al., 2009; 
Winckler and Yap, 2011). To investigate whether the polarized localization of APPL might depend on a similar mechanism in larval MB neurons, we sought to inhibit most types of endocytosis by expressing in the $\mathrm{MB}$ a dominant-negative form of $d y n a m i n /$ shibire $\left(s h i^{D N}\right)$ that is defective in hydrolysis of bound GTP, thus resulting in defective endocytosis (van der Bliek et al., 1993; Moline et al., 1999). In the presence of strong $s h i^{D N}$ expression, the lobes of the MB showed only mild structural phenotypes, but APPL was strongly mislocalized to the MB's calyx (Fig. 8A-B"). Dendritic mislocalization of Fas II (Fig. $8 C-D^{\prime \prime}$ ) and neuroglian (data not shown) were also observed in MB neurons with strong $s h i^{D N}$ expression. These results suggest that interference with dynamin-dependent endocytosis in vivo disrupts polarized localization of APP/APPL and other axonal membrane proteins in $\gamma$ neurons, and that dynamin/ shibire may have an important role in establishing and/or maintaining polarized localization of multiple axonal membrane proteins in the Drosophila CNS.

\section{Dynamin/shibire and AP-2 mutants} synthetically interact with $X 11$ mutants Based our findings that either lack of X11 or disruption of dynamin-dependent endocytosis led to mislocalization of axonal proteins, we further investigated whether there is a sensitive, synthetic interaction between loss of X11 function and disruption of endocytosis. Adult flies with loss of $X 11 /$ Mint or overexpression of $s h i^{D N}$ in the $\mathrm{MB}$ are viable and fertile. However, flies expressing RNAi to $X 11$ and $s h i^{D N}$ in the $\mathrm{MB}$ are embryonic lethal, indicating a robust genetic interaction exists between X11/Mint and dynamin/shibire. As the MB is dispensable for viability (i.e., flies lacking MBs are viable), this synthetic lethality is likely due to a basal level expression of the MB driver, suggesting a synthetic interaction between reduction of $\mathrm{X} 11$ function and decrease in endocytosis.

To further explore this genetic interaction at the level of APPL localization, we raised X11-shibire double mutants at a lower temperature than normal. Since GAL4-dependent expression is decreased at lower temperatures (Brand and Perrimon, 1993; Duffy, 2002), this approach results in more modest decreases in dynamin/ shibire function and X11 expression, leading to the emergence of viable larvae. Weak expression of $s h i^{D N}$ in $\gamma$ neurons causes almost no somatic or dendritic accumulation of APPL or Fas II, nor does it produce any noticeable defects in MB lobe morphology (Fig. 9A-D). Similarly, weak expression of RNAi X11 in MB neurons causes only mild dendritic mislocalization of APPL and Fas II and produces no defects in MB lobe morphology. However, weak expression of $s h i^{D N}$ and RNAi to X11 in the MB together results in dramatic enhancement of somatodendritic APPL and Fas II mislocalization and aberrant anatomical development of the medial and dorsal lobes (Fig. $9 E-H)$. This result indicates that a modest reduction in dynamindependent endocytosis significantly exacerbates axonal membrane protein mislocalization and structural phenotypes seen in X11 mutants.
We then investigated whether a hypomorphic allele of $\alpha$-adaptin $\left(A P 2^{06694}\right)$ also enhances dendritic mislocalization of axonal membrane proteins and structural defects in the MB of X11 mutants. $A P 2^{06694}$ disrupts function of the $\alpha$ subunit of the clathrin adaptor protein-2 (AP-2) complex that binds $\mathrm{PIP}_{2}$ (phosphatidyl-4,5bisphosphate) at the plasma membrane to facilitate endocytosis (González-Gaitán and Jäckle, 1997). Brains homozygous for the partial loss-of-function mutant $A P 2^{06694}$ contain no somatic or dendritic mislocalization of APPL or Fas II in $\gamma$ neurons and the MB lobes appear largely wild type (Fig. $10 A-D$ ). As noted previously, brains strongly expressing RNAi X11 in MB neurons show mislocalization of APPL and Fas II to the calyx, while the MB lobes appear largely wild type (Fig. $10 E, F)$. Interestingly, larvae mutant for both $X 11$ and $A P 2^{06694}$ show a pronounced increase in dendritic mislocalization of APPL and Fas II in $\gamma$ neurons. They also show MB lobe phenotypes strikingly similar to those of animals with pan-neuronal loss of X11 (Fig. 10G,H; compared with Fig. 4B). This result suggests that a reduction in clathrin-mediated endocytosis at the plasma membrane aggravates dendritic mislocalization of axonal membrane proteins and accelerates the appearance of developmental defects in X11/Mint mutants. Together, these robust genetic interaction studies suggest the possibility that either X11 proteins directly regulate endocytosis, or they act in a highly cooperative fashion with endocytosis to control polarized localization of certain axonally restricted membrane proteins, including APP/APPL.

\section{Discussion}

Here, we report the identification of a new set of evolutionarily conserved proteins that control polarized axonal protein local- 

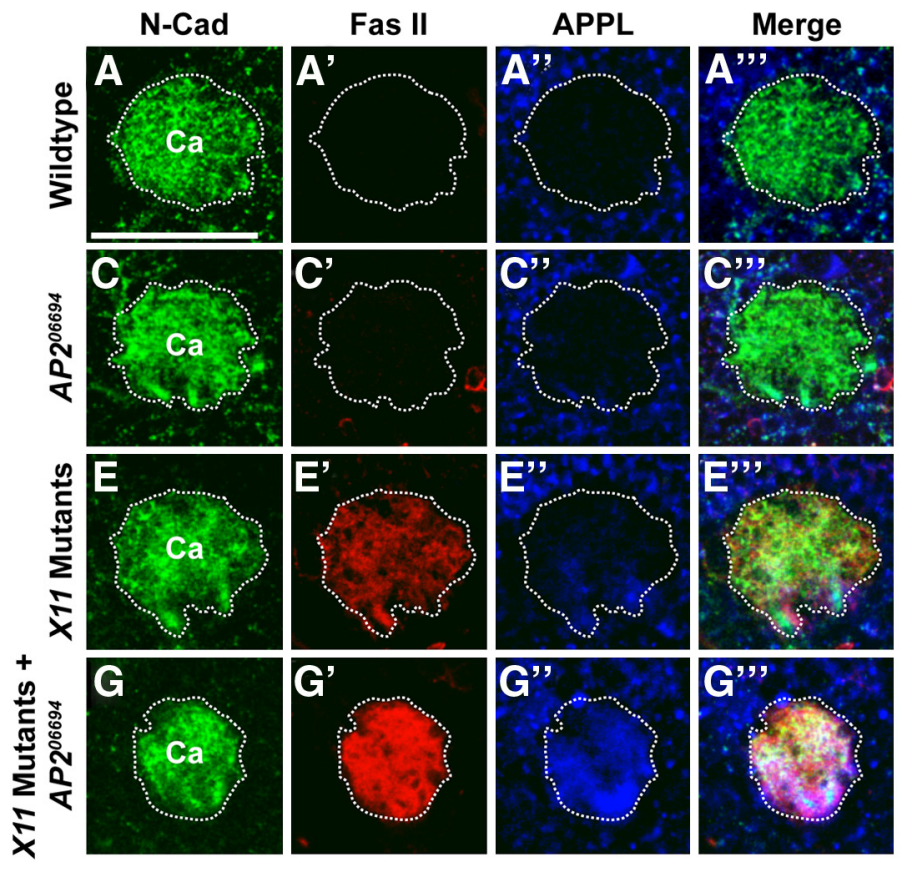

Figure 10. Attenuation of AP2-dependent endocytosis enhances MB phenotypes in X11 mutants. $\mathbf{A}-\boldsymbol{H}$, Staining of third instar brains against Drosophila $\mathrm{N}$-cadherin ( $\mathrm{N}$-Cad, green) identifies the MB's calyx (Ca), which is outlined by a dotted line. In addition, staining against fasciclin II (Fas II) identifies the MB's dorsal lobe (DL) and medial lobe (ML), which are also outlined by dotted lines. Scale bar, $50 \mu \mathrm{m}$. Larval brains expressing RNAi transgenes against X11 by MB-specific driver 0K107-GAL4 at $25^{\circ} \mathrm{C}$ and stained with anti-APPL and anti-Fas II antibodies show mislocalization of APPL (blue) and Fas II (red) to the calyx and Kenyon cells ( $\boldsymbol{A}-\boldsymbol{A}^{\prime \prime \prime}$ v $\left.\boldsymbol{E} \boldsymbol{E}-\boldsymbol{E}^{\prime \prime \prime}\right)$ and exhibit mostly wild-typeappearing lobes ( $\boldsymbol{B}$ vs $\boldsymbol{F}$ ). Furthermore, brains homozygous for $\alpha$-adaptin ${ }^{06694}$ (AP2 ${ }^{06694}$ ), a hypomorphic allele of the $\alpha$ subunit of clathrin adaptor protein-2 (AP-2), which binds $\mathrm{PIP}_{2}$ (phosphatidyl-4,5-bisphosphate) at the plasma membrane, show no detectable staining of APPL or Fas II in the calyx ( $\boldsymbol{A}-\boldsymbol{A}^{\prime \prime \prime \prime}$ vs $\boldsymbol{C}\left(\boldsymbol{C}^{\prime \prime \prime}\right)$ and have wild-type-appearing lobes ( $\boldsymbol{B}$ vs $\left.\boldsymbol{D}\right)$. In contrast, MB-specific silencing of X11 by RNAi in brains homozygous for AP2 ${ }^{06694}$ noticeably enhances mislocalization of APPL and Fas II to the calyx and Kenyon cells ( $\boldsymbol{E}-\boldsymbol{E}^{\prime \prime \prime}$ 'vs

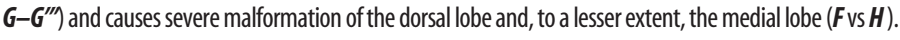

ization. First, we demonstrate that X11/Mint genes are required in vivo for dendritic exclusion and/or polarized localization of multiple, but not all, axonal membrane proteins. This list of proteins includes human APP, APPL, Fas II, and neuroglian, but not neurotactin. Mislocalization of these proteins in X11 mutants is not due to alteration of identity of the dendritic compartment. Thus, X11/Mint controls polarized localization of axonal membrane proteins through a process distinct from those required to establish and maintain these compartments. Second, we find that $\mathrm{X} 11$ is localized to the Golgi and also in areas adjacent to ER and endosomes. Third, we present in vivo data indicating that dendritic exclusion of APPL depends on an endocytic motif in APPL, and that APPL accumulates on the dendritic surface in X11 mutants. Fourth, we show direct disruption of endocytosis also leads to axonal protein mislocalization. Last, we establish that a modest reduction of X11 function and a modest disruption of endocytosis result in a dramatic synthetic genetic interaction. Our findings suggest the interesting possibility that X11/Mint proteins regulate endocytosis of certain axonal membrane proteins in dendrites (see below).

The neurons of Drosophila melanogaster provide an excellent system in which to study the polarized localization of membrane proteins in vivo (Rolls et al., 2007). Although Drosophila neurons are predominantly unipolar, they have been shown to compartmentally restrict membrane proteins, as observed in neurons of vertebrates (Rolls, 2011). Most of the work on polarized axonal protein localization has been performed in mammalian cultures of dissociated neurons. As effective as these culture systems are in identifying and investigating the role of these proteins, it remains
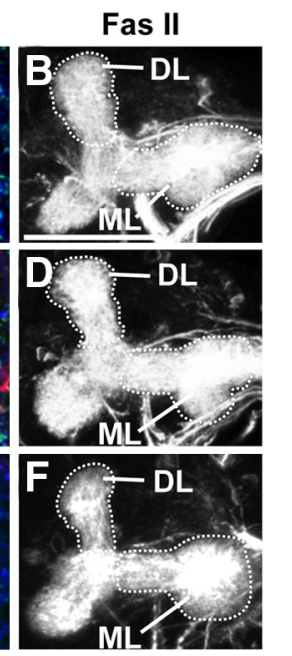

possible that cultured neurons are separated from other important sources of neuronal protein localization cues. The Drosophila MB offers an important system in which to dissect the mechanisms of protein localization in vivo.

In mammalian systems, several mechanisms have been postulated for establishing and maintaining polarized localization of axonal membrane proteins. Some axonal membrane proteins are thought to be trafficked along a "direct transport pathway" through the TGN, from which they are sorted and packaged into distinct carrier vesicles bound for the axon (Horton and Ehlers, 2003; Winckler and Yap, 2011). In contrast, axonal membrane proteins trafficked along an "indirect transport pathway" are first localized to the somatodendritic surface, with endocytosis being required for their rapid removal and proper localization to the axon (Sampo et al., 2003; Wisco et al., 2003).

How do X11/Mint proteins regulate axonal membrane protein localization? Our data favors a model where X11/Mint proteins control polarized localization of axonal membrane proteins via an "indirect transport pathway." The strong synthetic genetic interactions we observed between X11/Mint and dynamin, and to a lesser extent between X11/Mint and $\alpha$-adaptin, indicate that X11/Mint likely regulates, either directly or indirectly, endocytosis of certain axonal membrane proteins from the dendritic membrane (Fig. 11A). Our identification of X11L $\alpha$ at the Golgi is also consistent with a model in which X11/Mint exerts control over polarized localization of axonal membrane proteins at the TGN. Thus, X11/Mint may also be required at the TGN for sorting and/or packaging of APP and other axonal membrane proteins into carrier vesicles bound for the axon via a "direct transport pathway" rather than dendrites (Fig. 11B). These two models are not necessarily mutually exclusive. X11/Mint has been described as an adaptor protein with many diverse functions (Rogelj et al., 2006; Sakamoto and Seiki, 2009; Hara et al., 2011). Thus, it is possible that X11/Mint acts both in endocytosis and at Golgi to control polarized localization of certain axonal membrane proteins, such as APP/APPL. For example, in C. elegans, $X 11 / L I N-10$ is required for retrograde transport of endocytosed AMPA-type glutamate receptor GLR-1 from dendrites to Golgi outposts and the Golgi apparatus (Zhang et al., 2012). Similarly, X11/Mint proteins may also mediate sorting of dendritically localized protein from the TGN, and/or mediate return of dendritically mislocalized axonal membrane proteins to the Golgi in neurons of Drosophila.

Several observations in mammalian systems support a role of X11/Mint proteins in regulating endocytosis. First, X11/Mint physically binds both clathrin and PIP $_{2}$ (Okamoto and Südhof, 1997), which can independently bind AP-2 to initiate assembly of clathrin-coated pits and dynamin to control fission in endocytosis (Di Paolo and De Camilli, 2006). Second, expression of X11/Mint's PTB domain, as a dominant-negative, reduces endocytosis of APP with ApoER2 (apolipoprotein E receptor 2) in cultured neuroblas- 


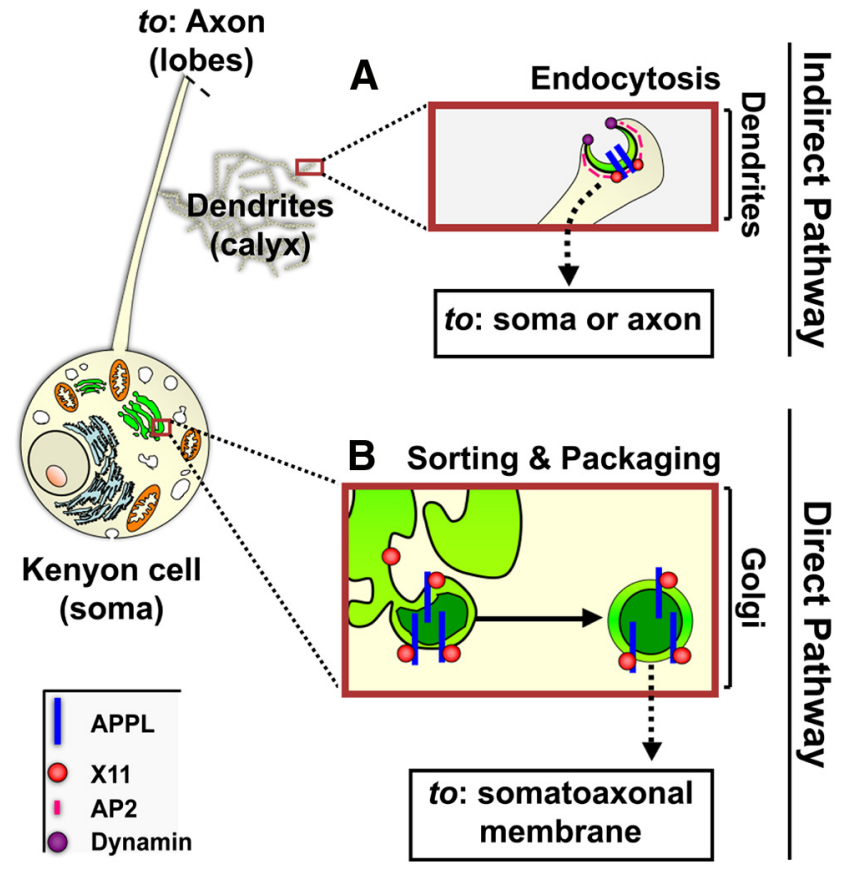

Figure 11. Cellular mechanisms of X11/Mint for controlling polarized localization of APP/ APPL in MB neurons. Depicted is a $\gamma$ neuron of the MB in a larval brain, containing Golgi (green) and other subcellular organelles in the soma. $\boldsymbol{A}$, Trafficking of the somatoaxonally restricted membrane protein APPL (blue) from Golgi leads to localization of APPL to dendrites. Once on the dendritic membrane, APPL is rapidly removed by dynamin (purple)-dependent endocytosis. This process is cooperatively facilitated by clathrin adaptor protein AP-2 (magenta) and binding of X11/Mint (red) to an endocytic motif (GYENPTY) in the intracellular domain of APPL. Those APPL proteins that reach the axon via endosomes have traveled there by an "indirect pathway." With loss of X11 function, endocytosis of APPL is impaired, which causes APPL proteins localized to the dendritic surface to accumulate there. B, At Golgi, whereX11/Mint is highly concentrated, APPL proteins may be preferentially sorted and packaged into axon-bound vesicles. APPL proteins delivered to the axon via Golgi-budded carrier vesicles have traveled there by a "direct pathway." If X11/Mint is required for sorting and/or packaging of APPL protein, then loss of X11/Mint function will cause APPL protein to be localized to both axon-bound and dendritebound vesicles. Since neither mechanism is mutually exclusive, X11/Mint may control polarized localization of APP/APPL both in dendrites and at Golgi.

toma cells (He et al., 2007). Finally, endocytosis of APP is significantly impaired in dissociated cortical neurons cultured from Cre-conditional $X 11 \alpha-X 11 \beta-X 11 \gamma$ knock-out mice (Chaufty et al., 2012). It is thus possible that Drosophila X11/Mint proteins can regulate endocytosis of APP/APPL at the plasma membrane. Work in mammalian cells also supports a role of X11/Mint proteins at the TGN. X11 $\gamma /$ Mint3 may control sorting and/or packaging of membrane proteins into secretory vesicles at the TGN (Teber et al., 2005; Zhang et al., 2009). Silencing of X11 $\gamma /$ Mint3 expression in several mammalian cell lines causes APP and other membrane proteins to preferentially localize to endosomes and/or the plasma membrane rather than at the TGN (Hill et al., 2003; Han et al., 2008; Shrivastava-Ranjan et al., 2008).

$\mathrm{X} 11 /$ Mint proteins may constitute a new group of proteins that localize other membrane proteins. In C. elegans, X11/LIN10 is required for polarized localization of the epidermal growth factor receptor to the basolateral membrane of vulva precursor cells (Rongo et al., 1998; Whitfield et al., 1999). Indeed, X11/LIN10 may function similarly to the Par3/Bazooka/aPKC (Suzuki and Ohno, 2006) to localize proteins in various contexts. One reason that this function of $\mathrm{X} 11 /$ Mint has not been uncovered previously may be due to the fact that there are three X11/Mint proteins in mammals, and they serve partially redundant functions.
Mutations in APP cause AD (Tanzi, 2012). Interestingly, changes in the transport and/or trafficking of APP have been suggested to promote $\mathrm{AD}$ pathogenesis by increasing amyloidogenic proteolysis of APP, and therefore production of the cytotoxic peptide A $\beta$ (Cataldo et al., 1997; Stokin et al., 2005). Notably, NEEP21, which is required for endosomal trafficking and polarized localization of the axonal membrane protein L1/ NgCAM (Yap et al., 2008), was also identified as an interactor of APP and modulator of A $\beta$ production (Norstrom et al., 2010). Thus, it will be interesting to determine whether loss of X11/Mint effects polarized localization and/or processing of APP in the adult brain, thereby contributing to the dysregulation and failure to maintain synaptic plasticity, and subsequently leading to AD.

Our findings suggest that mutations in X11/Mint could also lead to other neuropsychiatric disorders besides AD. Intriguingly, $X 11 \alpha$ and $X 11 \beta$ knock-out mice suffer from epileptic seizures (Saito et al., 2012), due to a malfunction of hyperpolarization-activated cyclic nucleotide-gated (HCN) channels. It remains to be seen whether the HCN channel is mislocalized in these knock-out mice. In addition, several studies have suggested that duplications of X11/Mint in the human genome might play a role in schizophrenia (Kirov et al., 2008) or autism (Maddox et al., 1999; Sutcliffe et al., 2003). However, it is not clear whether these partial duplications cause gain or loss of function. Thus, it will be interesting to determine whether these mutations in X11 can disrupt polarized localization of axonal membrane proteins and/or cause structural defects during neurodevelopment.

\section{References}

Aridor M, Hannan LA (2000) Traffic jam: a compendium of human diseases that affect intracellular transport processes. Traffic 1:836-851. CrossRef Medline

Aridor M, Hannan LA (2002) Traffic jams II: an update of diseases of intracellular transport. Traffic 3:781-790. CrossRef Medline

Ashburner M (1989) Drosophila, a laboratory manual. New York: Cold Spring Harbor Laboratory.

Ashley J, Packard M, Ataman B, Budnik V (2005) Fasciclin-II signals new synapse formation through amyloid precursor protein and the scaffolding protein dX11/Mint. J Neurosci 25:5943-5955. CrossRef Medline

Barr FA, Puype M, Vandekerckhove J, Warren G (1997) GRASP65, a protein involved in the stacking of Golgi cisternae. Cell 91:253-262. CrossRef Medline

Bel C, Oguievetskaia K, Pitaval C, Goutebroze L, Faivre-Sarrailh C (2009) Axonal targeting of Caspr2 in hippocampal neurons via selective somatodendritic endocytosis. J Cell Sci 122:3403-3413. CrossRef Medline

Benton R, St. Johnston D (2003) A conserved oligomerization domain in Drosophila Bazooka/PAR-3 is important for apical localization and epithelial polarity. Curr Biol 13:1330-1334. Medline

Blennow K, de Leon MJ, Zetterberg H (2006) Alzheimer's disease. Lancet 368:387-403. Medline

Bonifacino JS, Traub LM (2003) Signals for sorting of transmembrane proteins to endosomes and lysosomes. Annu Rev Biochem 72:395-447. CrossRef Medline

Borg JP, Ooi J, Levy E, Margolis B (1996) The phosphotyrosine interaction domains of X11 and FE65 bind to distinct sites on the YENPTY motif of amyloid precursor protein. Mol Cell Biol 16:6229-6241. Medline

Brand AH, Perrimon N (1993) Targeted gene expression as a means of altering cell fates and generating dominant phenotypes. Development 118 : 401-415. Medline

Cataldo AM, Barnett JL, Pieroni C, Nixon RA (1997) Increased neuronal endocytosis and protease delivery to early endosomes in sporadic Alzheimer's disease: neuropathologic evidence for a mechanism of increased beta-amyloidgenesis. J Neurosci 17:6142-6151. Medline

Chaufty J, Sullivan SE, Ho A (2012) Intracellular amyloid precursor protein sorting and amyloid-beta secretion are regulated by Src-mediated phosphorylation of Mint2. J Neurosci 32:9613-9625. CrossRef Medline

Chen CH, Huang H, Ward CM, Su JT, Schaeffer LV, Guo M, Hay BA (2007) 
A synthetic maternal-effect selfish genetic element drives population replacement in Drosophila. Science 316:597-600. CrossRef Medline

Clark IE, Jan LY, Jan YN (1997) Reciprocal localization of Nod and kinesin fusion proteins indicates microtubule polarity in the Drosophila oocyte, epithelium, neuron and muscle. Development 124:461-470. Medline

Deng H, Dodson MW, Huang H, Guo M (2008) The Parkinson's disease genes pink1 and parkin promote mitochondrial fission and/or inhibit fusion in Drosophila. Proc Natl Acad Sci 105:14503-14508. CrossRef Medline

Di Paolo G, De Camilli P (2006) Phosphoinositides in cell regulation and membrane dynamics. Nature 443:651-657. CrossRef Medline

Duffy JB (2002) GAL4 system in Drosophila: a fly geneticist's swiss army knife. Genesis 34:1-15. CrossRef Medline

Ganguly A, Feldman RM, Guo M (2008) Ubiquilin antagonizes presenilin and promotes neurodegeneration in Drosophila. Hum Mol Genet 17:293302. Medline

González-Gaitán M, Jäckle H (1997) Role of Drosophila alpha-Adaptin in presynaptic vesicle recycling. Cell 88:767-776. CrossRef Medline

Grenningloh G, Rehm EJ, Goodman CS (1991) Genetic analysis of growth cone guidance in Drosophila: fasciclin II functions as a neuronal recognition molecule. Cell 67:45-57. CrossRef Medline

Gross GG, Feldman RM, Ganguly A, Wang J, Yu H, Guo M (2008) Role of $X 11$ and ubiquilin as in vivo regulators of the amyloid precursor protein in Drosophila. PLoS ONE 3:e2495. CrossRef Medline

Han J, Wang Y, Wang S, Chi C (2008) Interaction of Mint3 with Furin regulates the localization of Furin in the trans-Golgi network. J Cell Sci 121:2217-2223. CrossRef Medline

Hara T, Mimura K, Abe T, Shioi G, Seiki M, Sakamoto T (2011) Deletion of the Ming3/Apba3 gene in mice abrogates macrophage functions and increases resistance to lipopolysaccharide-induced septic shock. J Biol Chem 286:32542-32551. CrossRef Medline

Hase M, Yagi Y, Taru H, Tomita S, Sumioka A, Hori K, Miyamoto K, Sasamura T, Nakamura M, Matsuno K, Suzuki T (2002) Expression and characterization of the Drosophila X11-like/Mint protein during neural development. J Neurochem 81:1223-1232. CrossRef Medline

He X, Cooley K, Chung CH, Dashti N, Tang J (2007) Apolipoprotein receptor 2 and X11alpha/beta mediate apolipoprotein E-induced endocytosis of amyloid-beta precursor protein and beta-secretase, leading to amyloidbeta production. J Neurosci 27:4052-4060. CrossRef Medline

Heisenberg M (2003) Mushroom body memoir: from maps to models. Nat Rev Neurosci 4:266-275. CrossRef Medline

Hemavathy K, Meng X, Ip YT (1997) Differential regulation of gastrulation and neuroectodermal gene expression by snail in the Drosophila embryo. Development 124:3683-3691. Medline

Higgins D, Burack M, Lein P, Banker G (1997) Mechanisms of neuronal polarity. Curr Opin Neurobiol 7:599-604. Medline

Hill K, Li Y, Bennett M, McKay M, Zhu X, Shern J, Torre E, Lah JJ, Levey AI, Kahn RA (2003) Munc18 interacting proteins: ADP-ribosylation factor-dependent coat proteins that regulate the traffic of betaAlzheimer's precursor protein. J Biol Chem 278:36032-36040. CrossRef Medline

Ho A, Morishita W, Atasoy D, Liu X, Tabuchi K, Hammer RE, Malenka RC, Südhof TC (2006) Genetic analysis of Mint/X11 proteins: essential presynaptic functions of a neuronal adaptor protein family. J Neurosci 26: 13089-13101. CrossRef Medline

Ho A, Liu X, Südhof TC (2008) Deletion of mint proteins decreases amyloid production in transgenic mouse models of Alheimer's disease. J Neurosci 28:14392-14400. CrossRef Medline

Horton AC, Ehlers MD (2003) Neuronal polarity and trafficking. Neuron 40:277-295. CrossRef Medline

Hortsch M, Bieber AJ, Patel NH, Goodman CS (1990a) Differential splicing generates a nervous system-specific form of Drosophila neuroglian. Neuron 4:697-709. CrossRef Medline

Hortsch M, Patel NH, Bieber AJ, Traquina ZR, Goodman CS (1990b) Drosophila neurotactin, a surface glycoprotein with homology to serine esterases, is dynamically expressed during embryogenesis. Development 110:1327-1340. Medline

Iwai Y, Hirota Y, Ozaki K, Okano H, Takeichi M, Uemura T (2002) DNcadherin is required for spatial arrangement of nerve terminals and ultrastructural organization of synapses. Mol Cell Neurosci 19:375-388. Medline

Kirov G, Gumus D, Chen W, Norton N, Georgieva L, Sari M, O’Donovan
MC, Erdogan F, Owen MJ, Ropers HH, Ullmann R (2008) Comparative genome hybridization suggests a role for NRXN1 and APBA2 in schizophrenia. Hum Mol Genet 17:458-465. Medline

Kondo M, Shiono M, Itoh G, Takei N, Matsushima T, Maeda M, Taru H, Hata S, Yamamoto T, Saito Y, Suzuki T (2010) Increased amyloidgenic processing of transgenic human APP in X11-like deficient mouse brain. Mol Neurodegener 5:35. CrossRef Medline

Lasiecka ZM, Yap CC, Caplan S, Winckler B (2010) Neuronal early endosomes require EHD1 for L1/NgCAM trafficking. J Neurosci 30:1648516497. CrossRef Medline

Lee JH, Lau KF, Perkinton MS, Standen CL, Shemilt SJ, Mercken L, Cooper JD, McLoughlin DM, Miller CC (2003) The neuronal adaptor protein X11alpha reduces Abeta levels in the brains of Alzheimer's APPswe Tg2576 transgenic mice. J Biol Chem 278:47025-47029. CrossRef Medline

Lee JH, Lau KF, Perkinton MS, Standen CL, Rogelj B, Falinska A, McLoughlin DM, Miller CC (2004) The neuronal adaptor protein X11beta reduces amyloid beta-protein levels and amyloid plaque formation in the brains of transgenic mice. J Biol Chem 279:49099-49104. CrossRef Medline

Lee T, Luo L (1999) Mosaic analysis with a repressible cell marker for studies of gene function in neuronal morphogenesis. Neuron 22:451-461. CrossRef Medline

Lee T, Lee A, Luo L (1999) Development of the Drosophila mushroom bodies: sequential generation of three distinct types of neurons from a neuroblast. Development 126:4065-4076. Medline

Lewis TL, Mao T, Arnold DB (2011) A role of myosin VI in the localization of axonal proteins. PLoS Biol 9:e1001021. CrossRef Medline

Li Y, Liu T, Peng Y, Yuan C, Guo A (2004) Specific functions of Drosophila amyloid precursor-like protein in the development of nervous system and nonneural tissues. J Neurobiol 61:343-358. CrossRef Medline

Maddox LO, Menold MM, Bass MP, Rogala AR, Pericak-Vance MA, Vance JM, Gilbert JR (1999) Autistic disorder and chromosome 15q11-q13: construction and analysis of a BAC/PAC contig. Genomics 62:325-331. CrossRef Medline

Margulies C, Tully T, Dubnau J (2005) Deconstructing memory in Drosophila. Curr Biol 15:R700-R713. CrossRef Medline

McLoughlin DM, Irving NG, Brownlees J, Brion JP, Leroy K, Miller CC (1999) Mint2/X11-like colocalizes with the Alzheimer's diseae amyloid precursor protein and is associated with neuritic plaques Eur J Neurosci 11:1988-1994. CrossRef

Mitchell JC, Ariff BB, Yates DM, Lau KF, Perkinton MS, Rogelj B, Stephenson JD, Miller CC, McLoughlin DM (2009) X11beta rescues memory and long-term potentiation deficits in Alzheimer's disease APPswe Tg2576 mice. Hum Mol Genet 18:4492-4500. CrossRef Medline

Moline MM, Southern C, Bejsovec A (1999) Directionality of wingless protein transport influences epidermal patterning in the Drosophila embryo. Development 126:4375-4384. Medline

Norstrom EM, Zhang C, Tanzi R, Sisodia SS (2010) Identification of NEEP21 as a beta-amyloid precursor protein-interacting protein in vivo that modulates amyloidgenic processing in vitro. J Neurosci 30:1567715685. CrossRef Medline

Okamoto M, Südhof TC (1997) Mints: Munc18-interacting proteins in synaptic vesicle exocytosis. J Biol Chem 272:31459-31464. CrossRef Medline

Rogelj B, Mitchell JC, Miller CC, McLoughlin DM (2006) The X11/Mint family of adaptor proteins. Brain Res Rev 52:305-315. CrossRef Medline

Rolls MM (2011) Neuronal polarity in Drosophila: sorting out axons and dendrites. Dev Neurobiol 71:419-429. CrossRef Medline

Rolls MM, Satoh D, Clyne PJ, Henner AL, Uemura T, Doe CQ (2007) Polarity and intraellular compartmentalization of Drosophila neurons. Neural Dev 2:7. CrossRef Medline

Rongo C, Whitfield CW, Rodal A, Kim SK, Kaplan JM (1998) LIN-10 is a shared component of the polarized protein localization pathways in neurons and epithelia. Cell 94:751-759. CrossRef Medline

Saito Y, Sano Y, Vassar R, Gandy S, Nakaya T, Yamamoto T, Suzuki T (2008) $\mathrm{X} 11$ proteins regulate the translocation of amyloid beta-protein precursor (APP) into detergent-resistant membrane and suppress the amyloidgenic cleavage of APP by beta-site-cleaving enzyme in brain. J Biol Chem 283: 35763-35771. CrossRef Medline

Saito Y, Inoue T, Zhu G, Kimura N, Okada M, Nishimura M, Kimura N, Murayama S, Kaneko S, Shigemoto R, Imoto K, Suzuki T (2012) Hyperpolarization-activated cyclic nucleotide gated channels: a potential 
molecular link between epileptic seizures and Abeta generation in Alzheimer's disease. Mol Neurodegener 7:50. CrossRef Medline

Sakamoto T, Seiki M (2009) Mint3 enhances the activity of hypoxiainducible factor-1 (HIF-1) in macrophages by suppressing the activity of factor inhibiting HIF-1. J Biol Chem 284:30350-30359. CrossRef Medline

Saluja I, Paulson H, Gupta A, Turner RS (2009) X11alpha halpinsufficiency enhances Abeta amyloid deposition in Alzheimer's disease transgenic mice. Neurobiol Dis 36:162-168. CrossRef Medline

Sampo B, Kaech S, Kunz S, Banker G (2003) Two distinct mechanisms target membrane proteins to the axonal surface. Neuron 37:611-624. CrossRef Medline

Sano Y, Syuzo-Takabatake A, Nakaya T, Saito Y, Tomita S, Itohara S, Suzuki $\mathrm{T}$ (2006) Enhanced amyloidogenic metabolism of the amyloid betaprotein precursor in the X11L-deficient mouse brain. J Biol Chem 281: 37853-37860. CrossRef Medline

Shrivastava-Ranjan P, Faundez V, Fang G, Rees H, Lah JJ, Levey AI, Kahn RA (2008) Mint3/X11gamma is an ADP-ribosylation factor-dependent adaptor that regulates the traffic of the Alzheimer's precursor protein from the trans-Golgi network. Mol Biol Cell 19:51-64. CrossRef Medline

Stokin GB, Lillo C, Falzone TL, Brusch RG, Rockenstein E, Mount SL, Raman R, Davies P, Masliah E, Williams DS, Goldstein LS (2005) Axonopathy and transport deficits early in the pathogenesis of Alzheimer's disease. Science 307:1282-1288. CrossRef Medline

Sutcliffe JS, Han MK, Amin T, Kesterson RA, Nurmi EL (2003) Partial duplication of the APBA2 gene in chromosome 15q13 corresponds to duplicon structures. BMC Genomics 4:15. CrossRef Medline

Sutula TP (2004) Mechanisms of epilepsy progression: current theories and perspectives from neurplasticity in adulthood and development. Epilepsy Res 60:161-171. CrossRef Medline

Suzuki A, Ohno S (2006) The PAR-aPKC system: lessons in polarity. J Cell Sci 119:979-987. CrossRef Medline

Tanzi RE (2012) The genetics of Alzheimer disease. Cold Spring Harb Perspect Med 2:pii: a006296. CrossRef Medline

Teber I, Nagano F, Kremerskothen J, Bilbilis K, Goud B, Barnekow A (2005) Rab6 interacts with the mint3 adaptor protein. Biol Chem 386:671-677. Medline

Torroja L, Luo L, White K (1996) APPL, the Drosophila member of the APP-family, exhibits differential trafficking and processing in CNS neurons. J Neurosci 16:4638-4650. Medline

Torroja L, Packard M, Gorczyca M, White K, Budnik V (1999) The Drosophila $\beta$-amyloid precursor protein homolog promotes synapse differentiation at the neuromuscular junction. J Neurosci 19:7793-7803. Medline

van der Bliek AM, Redelmeier TE, Damke H, Tisdale EJ, Meyerowitz EM,
Schmid SL (1993) Mutations in human dynamin block an intermediate stage in coated vesicle formation. J Cell Biol 122:553-563. CrossRef Medline

Vishnu S, Hertenstein A, Betschinger J, Knoblich JA, Gert de Couet H, Fischbach KF (2006) The adaptor protein X11Lalpha/Dmint1 interacts with the PDZ-binding domain of the cell recognition protein Rst in Drosophila. Dev Biol 289:296-307. CrossRef Medline

Walsh CA, Engle EC (2010) Allelic diversity in human developmental neurogenetics: insights into biology and disease. Neuron 68:245-253. CrossRef Medline

Wang J, Ma X, Yang JS, Zheng X, Zugates CT, Lee CH, Lee T (2004) Transmembrane/juxtamembrane domain-dependent Dscam distribution and function during mushroom body neuronal morphogenesis. Neuron 43 : 663-672. CrossRef Medline

Whitfield CW, Bénard C, Barnes T, Hekimi S, Kim SK (1999) Basolateral localization of the Caenorhabditis elegans epidermal growth factor receptor in epithelial cells by the PDZ protein LIN-10. Mol Biol Cell 10:20872100. Medline

Winckler B, Yap CC (2011) Endocytosis and endosomes at the crossroads of regulating trafficking of axon outgrowth-modifying receptors. Traffic 12: 1099-1108. CrossRef Medline

Wisco D, Anderson ED, Chang MC, Norden C, Boiko T, Fölsch H, Winckler B (2003) Uncovering multiple axonal targeting pathways in hippocampal neurons. J Cell Biol 162:1317-1328. CrossRef Medline

Yap CC, Wisco D, Kujala P, Lasiecka ZM, Cannon JT, Chang MC, Hirling H, Klumperman J, Winckler B (2008) The somatodendritic endosomal regulator NEEP21 facilitates axonal targeting of L1/NgCAM. J Cell Biol 180:827-842. CrossRef Medline

Yap CC, Lasiecka ZM, Caplan S, Winckler B (2010) Alterations of EHD1/ EHD4 protein levels interfere with L1/NgCAM endocytosis in neurons and disrupt axonal targeting. J Neurosci 30:6646-6657. CrossRef Medline

Yun J, Cao JH, Dodson MW, Clark IE, Kapahi P, Chowdhury RB, Guo M (2008) Loss-of-function analysis suggests that Omi/HtrA2 is not an essential component of the PINK1/PARKIN pathway in vivo. J Neurosci 28:14500-14510. CrossRef Medline

Zhang D, Isack NR, Glodowski DR, Liu J, Chen CC, Xu XZ, Grant BD, Rongo C (2012) RAB-6.2 and the retromer regulate glutamate receptor recycling through a retrograde pathway. J Cell Biol 196:85-101. CrossRef Medline

Zhang Y, Wang YG, Zhang Q, Liu XJ, Liu X, Jiao L, Zhu W, Zhang ZH, Zhao XL, He C (2009) Interaction of Mint2 with TrkA is involved in regulation of nerve growth factor-induced neurite outgrowth. J Biol Chem 284: 12469-12479. CrossRef Medline 